\title{
Overborrowing and Systemic Externalities in the Business Cycle
}

\author{
Javier Bianchi * \\ University of Maryland
}

First Draft: December 2008

This Draft: August 2009

\begin{abstract}
Credit constraints that link a private agent's debt to market-determined prices embody a credit externality that drives a wedge between competitive and constrained socially optimal equilibria, inducing private agents to "overborrow." The externality arises because agents fail to internalize the price effects of additional borrowing when the credit constraint binds. We quantify the effects of this inefficiency in a two-sector DSGE model of a small open economy calibrated to emerging markets. The credit externality increases the probability of financial crises by a factor of 7 and causes the maximum drop in consumption to increase by 10 percentage points.
\end{abstract}

Keywords: Financial crises, amplification effects, business cycles, constrained efficiency JEL Codes: D62,E32,E44,F32,F41

*I am greatly indebted to Enrique Mendoza for his guidance and advice. I am also grateful to Anton Korinek and John Shea for encouragement and invaluable suggestions. For useful suggestions and comments, I thank Juan Dubra, Bora Durdu, Pablo D'Erasmo, Bertrand Gruss, Alessandro Rebucci and seminar participants at the University of Maryland, Universidad de Montevideo and Atlanta Fed. This research was completed while I was visiting the Atlanta Fed, which I thank for its hospitality. bianchi@econ.umd.edu 


\section{Introduction}

The current financial crisis has shown that economies can experience virulent recessions that differ from typical business cycle downturns. In emerging markets, crises often are preceded by tranquil times, during which the emerging economy experiences an increase in debt before suddenly losing access to the international financial market. The disruption associated with these episodes has led to a concern in academic and policy circles that countries borrow excessively. From the individual standpoint, however, if agents decide to borrow heavily and become exposed to financial distress, it means that the perceived benefits outweigh the perceived costs. This raises the first question we ask in this paper: Are the incidence and the severity of financial crises optimal from the standpoint of society as a whole? We analyze this question by comparing the laissez-faire equilibrium to the allocations of a benevolent social planner who faces the same resource and financial constraints as the private economy. Our answer is negative: a credit externality induces agents to overborrow because they fail to internalize that their financing decisions entail amplification effects.

The next logical question is: How large are the differences between the privately optimal and the socially optimal allocations? To provide an answer, we quantify the effects of the inefficiency in a two-sector dynamic stochastic general equilibrium (DSGE) model of a small open economy with an occasionally binding endogenous credit constraint calibrated to emerging markets. The credit externality increases the long-run probability of a financial crisis from 1.1 percent to 8.2 percent and causes the maximum drop in consumption to increase from 14 percent to 24 percent.

Our model features a credit constraint that requires debt, denominated in the international unit of account (i.e., tradable goods), not to exceed a fraction of income composed of tradables and non-tradables, as in Mendoza (2002). While the international demand for

tradable goods is perfectly elastic, the price of non-tradables adjusts to equilibrate domestic supply and demand in the non-tradable sector. Because debt is partially leveraged in non-tradables income, changes in the relative price of non-tradable goods can induce sharp and sudden adjustments in access to foreign financing. When a negative shock to income makes the credit constraint binding, the economy suffers the economic dislocation typically 
associated with an emerging market crisis. Demand for consumption goods falls, which puts downward pressure in the price of non-tradables, i.e the real exchange rate. The resulting drop in the real exchange rate leads to a further tightening of the credit constraint, setting in motion Fisher's debt deflation channel, by which declines in consumption, real exchange rate, and access to foreign financing mutually reinforce each other. Private agents form rational expectations about the evolution of macroeconomic variables, in particular the real exchange rate, and correctly perceive the risks and benefits of their borrowing decisions. Nevertheless, they fail to internalize the general equilibrium effects of the contraction in consumption in prices. This is a pecuniary externality that would not impede market efficiency in the absence of the adverse debt-deflation effects. However, by reducing the amount of debt ex-ante, a social planner can mitigate the fall in the real exchange rate during a crisis. Because the real exchange rate affects the borrowing capacity of the economy, this intervention can make all agents better off. ${ }^{1}$

On the normative side, the inefficiency of the decentralized equilibrium implies a role for financial regulation taking financial frictions as given. We show that a tax on debt designed to make agents internalize the social costs generated by leverage can attain the constrained social optimum. In the calibrated version of our model, the tax on debt necessary to implement the constrained efficient allocation is 4.5 percent on average, increasing with leverage and probability of a future financial crisis. The welfare gains from correcting the externality are associated with a smoother business cycle and are about 0.1 percent of permanent consumption on average. Moreover, as a result of the macro-prudential nature of optimal policy, the benefits of the correcting the externality are maximized outside crisis states, particularly in the run-up to a financial crash.

Our work builds on extensive research on the financial accelerator that started with Fisher (1933) and developed further with the contributions of Bernanke and Gertler (1989), Kiyotaki and Moore (1997), Bernanke, Gertler, and Gilchrist (1999), and Aiyagari and Gertler (1999). In the emerging market literature, Gertler, Gilchrist, and Natalucci (2007) and Mendoza (2008) have shown that the quantitative predictions of a DSGE model with financial

\footnotetext{
${ }^{1}$ Note the analogy with more traditional externalities: for example, pollution from a factory directly affects the environment. In our model, individual leverage amplifies the price responses to negative shocks and affects through this channel the borrowing capacity of the economy.
} 
frictions are consistent with key features of emerging market crises. Our contribution to this literature is twofold. First, we show that the financial accelerator creates an externality by which excessive borrowing leads to a level of amplification that can differ from the optimal amplification in a quantitatively significant way. Second, we propose a policy that achieves the constrained social optimal allocations and reduces the incidence and severity of financial crises.

Our paper is in the spirit of the theoretical literature that studies the role of pecuniary externalities in financial markets. Some prominent examples include: Caballero and Krishnamurthy (2001) and Korinek (2009a) in the emerging market literature and Lorenzoni (2008) and Farhi, Golosov, and Tsyvinski (2009) in the closed economy macroeconomic literature. ${ }^{2}$ These studies have been primarily static and were designed to address qualitative effects. Therefore, the quantitative significance of pecuniary externalities, which is important for determining to what extent regulation is desirable for correcting this market failure, remains an open question. This paper fills in this gap by providing a dynamic stochastic general equilibrium framework, where the magnitudes of the distortions introduced by pecuniary externalities can be analyzed and assessed quantitatively.

The existent literature has explored different explanations of why countries may borrow excessively. One explanation is moral hazard: banks may lend excessively to take advantage of some form of government guarantees (see e.g. McKinnon and Pill, 1996; Schneider and Tornell, 2004). Another explanation suggested in policy debates is that emerging markets tend to overborrow when the lending decisions of foreign investors are guided by macroeconomic indicators rather than by evaluating an individual borrower's abilities to repay. Nevertheless, Uribe (2006) found that both an equilibrium with an aggregate borrowing limit and where the borrowing limit is imposed on individuals deliver the same borrowing decisions. This result represents a form of "no overborrowing". We will show, however, that in the presence of multiple goods, because individual agents fail to internalize the adverse debt-deflation effects of additional borrowing, the private economy exhibits "overborrowing."

The results of our normative analysis are also related to Christiano, Gust, and Roldos

\footnotetext{
${ }^{2}$ The externality result of these papers is related to the more general proposition that economies with incomplete markets are generically inefficient (see e.g. Geneakoplos and Polemarchakis, 1986 and Stiglitz, 1982).
} 
(2004) and Benigno et al. (2009) which show that stabilization plans can be optimal when emerging markets face financial crises. While the policy implications of Christiano et al. (2004) and Benigno et al. (2009) suggest the need of a "reactive" policy to reduce the severity of financial crises once they take place, our normative analysis suggests the need of a "prudential" policy during relatively tranquil times to reduce the economy's vulnerability to these episodes. The fact that many stabilization plans have fallen during recent emerging market crises may lend support to macro-prudential policy, which helps prevent the economy from exposure to these episodes. Our paper provides a quantitative framework to analyze policies that have this objective.

Our results also are related to the ongoing debate on the desirability of financial globalization. Standard neoclassical theory predicts that the liberalization of the capital account will generate international risk-sharing and efficient capital reallocation. Critics like Stiglitz (2002) and Bhagwati (2004) have argued against financial globalization on the grounds that it makes emerging markets vulnerable to financial crises. Recently, Korinek (2008) develops this argument further in a theoretical model and shows how taxes on particular capital flows can improve welfare. Our paper contributes to this debate by undertaking a quantitative investigation of how tax on capital flows can be effective in reducing the vulnerability to financial crises while still allowing the benefits from access to the global financial market.

The remainder of the paper is organized as follows: Section 2 presents the analytical framework; Section 3 characterizes the decentralized equilibrium and the social planner's problem, in addition to demonstrating the externality results of the paper; Section 4 and Section 5 analyze the quantitative significance of the credit externality; Section 6 discusses welfare and policy implications; and, Section 7 provides conclusions.

\section{Analytical Framework}

Consider an endowment version of the representative-agent two-sector DSGE-SOE model with tradable and non-tradable goods. Tradable goods can be used for external borrowing and lending transactions; non-tradable goods have to be consumed in the domestic economy. We assume that debt is denominated in units of tradables with a credit constraint that links credit-market access to income, including non-tradable income. This setup, proposed by 
Mendoza (2002), captures the phenomenon called "liability dollarization" in a flexible-price environment, which the empirical literature has emphasized as being a key transmission mechanism in emerging markets crises. ${ }^{3,4}$

\subsection{Households}

There is a continuum of identical, infinitely lived households of measure unity. Preferences of the representative household are given by:

$$
E_{0}\left\{\sum_{t=0}^{\infty} \beta^{t} u\left(c_{t}\right)\right\}
$$

In this expression, $E(\cdot)$ is the expectation operator, and $\beta$ is the discount factor. The period utility function $u(\cdot)$ has the constant-relative-risk-aversion (CRRA) form. The consumption basket $c_{t}$ is an Armington-type CES aggregator with elasticity of substitution $1 /(\eta+1)$ between tradable $c^{T}$ and non-tradable goods $c^{N}$ given by:

$$
c_{t}=\left[\omega\left(c_{t}^{T}\right)^{-\eta}+(1-\omega)\left(c_{t}^{N}\right)^{-\eta}\right]^{-\frac{1}{\eta}}, \quad \eta>-1, \omega \in(0,1)
$$

Households receive a random endowment of tradables $y_{t}^{T}$ and a constant endowment of non-tradables $y^{N}$. The tradable endowment shock has a compact support and follows a finite-state stationary Markov process. Foreign assets are restricted to a one period, noncontingent bond denominated in units of tradables that pay a fixed interest rate $r$, determined exogenously in the world market. To have a well defined ergodic distribution of foreign assets, i.e. a well defined stochastic steady state, we assume that the discount factor and the world interest rate are such that $\beta(1+r)<1 .^{5}$

Normalizing the price of tradables to 1 and denoting the price of non-tradable goods by

\footnotetext{
${ }^{3}$ The liability dollarization refers to the phenomenon that debts in emerging economies are generally denominated in units of tradable goods or in hard currencies, but they are partially leveraged on the incomes and assets of the large non tradable sector typical of these economies.

${ }^{4}$ See Calvo, Izquierdo, and Loo-Kung, 2006 and Guidotti, Sturzenegger, Villar, de Gregorio, and Goldfajn, 2004.

${ }^{5}$ When $\beta(1+r)<1, \beta^{t}(1+r)^{t} u^{\prime}\left(c_{t}\right)<1$ is a non-negative supermartingale that converges almost surely to a non-negative random variable (see Chamberlain and Wilson (2000)). Hence the long-run averages of assets and consumption also remain finite. In contrast, with $\beta(1+r) \geq 1$, assets diverge to infinity in the long-run because the marginal utility converges to zero almost surely. See Schmitt-Grohe and Uribe (2003) for other specifications used for this purpose.
} 
$p^{N}$, the budget constraint is:

$$
b_{t+1}+c_{t}^{T}+p_{t}^{N} c_{t}^{N}=y_{t}^{T}+b_{t}(1+r)+p_{t}^{N} y^{N}
$$

where $b_{t+1}$ denotes bond holdings that households choose at the beginning of time $t$. We maintain the convention that positive values of $b$ denote assets. ${ }^{6}$ We assume that markets are not only incomplete but also imperfect. Following Mendoza (2002), households can borrow up to a fraction $\kappa$ of their income, so that:

$$
b_{t+1} \geq-\kappa\left(p_{t}^{N} y^{N}+y_{t}^{T}\right)
$$

This credit constraint imposes an upper bound on leverage, defined as the debt-to-income ratio, and captures the fact that a higher level of income supports debt repayment incentives when there are problems of asymmetric information (see e.g Stiglitz and Weiss, 1981). Although this constraint is not derived from an optimal contract, our results are robust to any framework where the private agent's borrowing ability depends on the real exchange rate. Moreover, the empirical evidence widely supports the use of borrowing constraints of this form in determining maximum loan amounts and in setting borrowers' qualification criteria, particularly in mortgage loans and in consumer debt contracts (see .e.g. Arellano and Mendoza, 2003 for a discussion).

Given a stochastic sequence of prices, the consumer problem consists of maximizing the expected present discounted value of utility (1) subject to the sequence of budget and credit constraints given by (2) and (3). The optimization problem for a typical household of this small open economy is analogous to the optimization problem of a single household that faces idiosyncratic income shocks (e.g., Aiyagari, 1994, or Hugget, 1993). As in those models, agents accumulate precautionary savings to insure against a possible long sequence of adverse income shocks. When households are heavily indebted and the economy receives a negative shock, they will face a binding credit constraint. ${ }^{7}$

\footnotetext{
${ }^{6}$ As there is only one asset, gross and net foreign assets (NFA) coincide.

${ }^{7}$ Note also that CRRA preferences and CES aggregator imply that $\lim _{c^{T} \rightarrow 0^{+}} u^{\prime}(c) c_{T}\left(c^{T}, c^{N}\right)=$ $\lim _{c^{N} \rightarrow 0^{+}} u^{\prime}(c) c_{N}\left(c^{T}, c^{N}\right)=+\infty$ so agents will self-insure to rule out stochastic sequences that could expose them to zero consumption of tradables or non-tradables at any date or state of nature.
} 


\subsection{Decentralized Competitive Equilibrium Conditions}

The optimality conditions of the household problem are:

$$
\begin{gathered}
\lambda_{t}=u^{\prime}(t) c_{T}(t) \\
p_{t}^{N}=\left(\frac{1-\omega}{\omega}\right)\left(\frac{c_{t}^{T}}{c^{N}}\right)^{\eta+1} \\
\lambda_{t}=\beta E_{t} \lambda_{t+1}(1+r)+\mu_{t} \\
b_{t+1}+\kappa\left(p_{t}^{N} y^{N}+y_{t}^{T}\right) \geq 0, \quad \text { with }=\text { if } \mu_{t}>0
\end{gathered}
$$

where $\lambda$ is the non-negative multiplier associated with the budget constraint and $\mu$ is the non-negative multiplier associated with the credit constraint. The optimality condition (4) equates the marginal utility of tradable consumption to the shadow value of current wealth. Condition (5) is a static condition linking the marginal rate of substitution of two goods, tradables and non-tradables, to their relative price. Equation (6) determines the intertemporal allocation of wealth and consumption. When the credit constraint is binding, there is a wedge between the current shadow value of wealth and the expected value of reallocating wealth to the next period given by the shadow price of relaxing the credit constraint $\mu_{t}$. Condition (7) is the complementary slackness condition.

Since households are identical, market clearing conditions are given by:

$$
\begin{gathered}
c^{N}=y^{N} \\
c^{T}=y^{T}+b_{t}(1+r)-b_{t+1}
\end{gathered}
$$

Note that equation (5) implies that a reduction in $c_{t}^{T}$ generates on equilibrium a reduction in $p_{t}^{N}$, which by equation (3) reduces the collateral value. Therefore, the credit constraint produces asymmetric responses of the economy to aggregate shocks, as in Mendoza (2002). ${ }^{8}$ A binding credit constraint amplifies the consumption drop in response to negative shocks to tradables' output, relative to perfect capital markets. But, no amplification effects occur

\footnotetext{
${ }^{8}$ See Mendoza (2006) for an illustrative deterministic example of this mechanism.
} 
when the credit constraint is slack. As in a standard model of insurance, the demand for borrowing is decreasing with current income $y_{t}^{T}$. As a result, for a given $p_{t}^{N}$ there is a threshold $\hat{y}_{t}^{T}$, such that for any $y_{t}^{T}<\hat{y}_{t}^{T}$, the constraint becomes binding.

Given an initial foreign asset position $b_{0}$, the stochastic process for $y^{T}$ and the world real interest rate $r$, the competitive equilibrium is fully characterized by a set of stochastic sequences $\left\{c_{t}^{T}, c_{t}^{N}, b_{t+1}, p_{t}^{N}, \lambda_{t}, \mu_{t}\right\}_{t=0}^{\infty}$ such that (4)-(9) are satisfied.

\section{Recursive Problem}

\subsection{Decentralized Competitive Equilibrium}

We start by describing the optimization problem of a typical agent in recursive form. A crucial feature of this setup is that aggregate bond holdings, denoted by $B$, constitute a state variable in this problem. This feature arises because the representative agent needs to forecast aggregate variables beyond his control to form expectations of future prices. In particular, the representative agent needs to forecast aggregate tradable and non-tradable consumption to predict the price of non-tradables. Because the endowment of non-tradables is fixed, the forecast of non-tradable consumption is simply $y^{N}$. To forecast tradable consumption, the representative agent must conjecture a law of motion for the aggregate foreign asset position. We denote the perceived law of motion for the aggregate foreign asset position by $\Gamma(\cdot)$, which is a function of the current aggregate state $\left(B, y^{T}\right)$. Using $(5)$, the forecast price for non-tradables at time $t$ can be expressed as:

$$
p^{N}\left(B_{t}, y_{t}^{T}\right)=\left(\frac{1-\omega}{\omega}\right)\left(\frac{y_{t}^{T}+B_{t}(1+r)-\Gamma\left(B_{t}, y_{t}^{T}\right)}{y^{N}}\right)^{\eta+1}
$$

The optimization problem of a typical agent is:

$$
V\left(b, B, y^{T}\right)=\max _{b^{\prime}, c^{T}, c^{N}} u\left(c\left(c^{T}, c^{N}\right)\right)+\beta E_{t} V\left(b^{\prime}, B^{\prime}, y^{T^{\prime}}\right)
$$

s.t. 


$$
\begin{aligned}
& b^{\prime}+p^{N}\left(B, y^{T}\right) c^{N}+c^{T}=y^{T}+b(1+r)+p^{N}\left(B, y^{T}\right) y^{N} \\
& b^{\prime} \geq-\kappa\left(p^{N}\left(B, y^{T}\right) y^{N}+y^{T}\right) \\
& B^{\prime}=\Gamma\left(B, y^{T}\right)
\end{aligned}
$$

where we have followed the convention of denoting current variables without subscript and denoting next period variables with the prime superscript.

The solution to the household problem provides decision rules for individual bond holdings $\hat{b}\left(b, B, y^{T}\right)$, tradable consumption $\hat{c}^{T}\left(b, B, y^{T}\right)$ and non-tradable consumption $\hat{c}^{N}\left(b, B, y^{T}\right)$. The household optimization problem induces a mapping from the perceived law of motion for the aggregate foreign asset position to an actual law of motion, given simply by the representative agent's choice $\hat{b}\left(B, B, y^{T}\right)$. In a rational expectations equilibrium, as defined below, these two laws of motion must coincide.

\section{Definition 1 (Decentralized Recursive Competitive Equilibrium)}

$A$ decentralized recursive competitive equilibrium for the $S O E$ is a pricing function $p^{N}\left(B, y^{T}\right)$, a perceived law of motion $\Gamma\left(B, y^{T}\right)$ and decision rules $\left\{\hat{b}\left(b, B, y^{T}\right), \hat{c}^{T}\left(b, B, y^{T}\right), \hat{c}^{N}\left(b, B, y^{T}\right)\right\}$ such that the following conditions hold:

1. Household optimization: taking as given $p^{N}\left(B, y^{T}\right)$ and $\Gamma\left(B, y^{T}\right)$, $\left\{\hat{b}\left(b, B, y^{T}\right), \hat{c}^{N}\left(b, B, y^{T}\right), \hat{c}^{N}\left(b, B, y^{N}\right)\right\}$ solve the optimization problem of the household.

2. Rational expectation condition: the perceived law of motion is consistent with the actual law of motion: $\Gamma\left(B, y^{T}\right)=\hat{b}\left(B, B, y^{T}\right)$.

3. Markets clear: $y^{N}=\hat{c}^{N}\left(B, B, y^{T}\right)$ and $\hat{b}\left(b, B, y^{T}\right)+\hat{c}^{T}\left(b, B, y^{T}\right)=y^{T}+B(1+r)$.

\subsection{Social Planner}

We previously described the equilibrium achieved when agents take aggregate variables as given, particularly the price of non-tradables. Consider now a benevolent social planner with restricting planning abilities. We assume that the social planner can directly choose 
the level of debt subject to the credit constraint but let goods market clear competitively. ${ }^{9}$ As opposed to the representative agent, a social planner internalizes the effects of an agent's decisions on the price of non-tradables. Critically, the social planner realizes that a lower debt level in a crisis mitigates the reduction in the price of non-tradables. As explained above, a lower price of non-tradables tightens further the borrowing ability and amplifies the reduction in tradable consumption. As a result, we will show that the decentralized equilibrium allocation is not constrained Pareto optimum, as defined below.

\section{Definition 2 (Constrained Efficiency)}

Let $\left\{c_{t}^{T}, c_{t}^{N}, b_{t+1}\right\}_{t=0}^{\infty}$ be the allocations of the competitive equilibrium yielding utility $\hat{V}$. The competitive equilibrium is constrained Pareto optimum if a planner who directly chooses $\left\{b_{t+1}\right\}_{t=0}^{\infty}$ subject to the credit constraint, but let the goods market clear competitively cannot improve welfare for the consumer over $\hat{V}$.

The social planner's optimization problem consist of maximizing (1) subject to (3),(5), (8) and (9). Thus, we can express the the social planner's optimization problem in recursive form as: ${ }^{10}$

$$
\begin{aligned}
& V\left(b, y^{T}\right)=\max _{b^{\prime}, c^{T}} u\left(c\left(c^{T}, y^{N}\right)\right)+\beta E V\left(b^{\prime}, y^{T^{\prime}}\right) \\
& \text { s.t. } \\
& b^{\prime}+c^{T}=y^{T}+b(1+r) \\
& b^{\prime} \geq-\kappa\left(\frac{1-\omega}{\omega}\left(\frac{c^{T}}{y^{N}}\right)^{\eta+1} y^{N}+y^{T}\right)
\end{aligned}
$$

Using superscript "SP" to distinguish the multipliers of the social planner from the decentralized equilibrium, this results in the following first order conditions for the social planner:

$$
\begin{gathered}
\lambda_{t}^{S P}=u^{\prime}(t) c_{T}(t)+\mu_{t}^{S P} \Psi_{t} \\
\lambda_{t}^{S P}=\beta E_{t} \lambda_{t+1}^{S P}(1+r)+\mu_{t}^{S P}
\end{gathered}
$$

\footnotetext{
${ }^{9}$ This notion of constrained efficiency is in the spirit of Diamond (1967).

${ }^{10}$ Note that we substitute (5) and (8) in (3) to obtain the equilibrium price.
} 
where $\Psi_{t}=\kappa \frac{\partial p_{t}^{N}}{\partial c_{t}^{T}} y^{N}=\kappa \frac{1-\omega}{\omega}\left(\frac{c_{t}^{T}}{y^{N}}\right)^{\eta}(1+\eta)$ represents how the collateral value changes in equilibrium when there is a change in tradable consumption. This variable is not present in the corresponding equation for the decentralized equilibrium (4), since decentralized agents take the price of non-tradables as given. Condition (13) states that at the social optimum, the shadow value of current wealth equals the marginal utility of consumption plus the value of relaxing the credit constraint that arises from the subsequent increase in the price of non-tradables. Condition (14) is identical to the decentralized equilibrium condition (6). Note that if the constraint does not bind in the stochastic steady states of the decentralized equilibrium and the social planner, the conditions characterizing both environments are identical and the allocations therefore coincide.

Consider an initial situation where the credit constraint is satisfied with equality, but is not binding, and a negative shock tightens the credit constraint by one unit. Because atomistic agents take prices as given, the perceived decrease in tradable consumption is one unit. However, the social planner internalizes the fact that a decrease in tradable consumption decreases the price of non-tradables, making the constraint even more binding, as captured by $\Psi_{t}$. As a result, the social shadow value of wealth exceeds the private shadow value of wealth when the credit constraint binds.

\section{Proposition 1 (Wealth Undervaluation)}

Assume the credit constraint binds at time $t$; let $\left(b_{t}, y_{t}^{T}\right)$ be the initial state and $\left(c_{t}^{T}, c_{t}^{N}, b_{t+1}\right)$ be the allocations of the decentralized equilibrium and the social planner. The social planner's shadow value of wealth is strictly higher than the decentralized agent's shadow value of wealth.

Proof. The proof follows simply by comparing (4) and (13), which yields that the social

shadow value of wealth exceeds the private value by $\mu_{t}^{S P} \Psi_{t}$. a To see more clearly why the decentralized equilibrium generates overborrowing, suppose that at time $t$ the constraint is not binding, but it may become a binding constraint in the next period if a sufficiently high leverage is chosen. Using (6) and (4), the Euler equation for consumption for the decentralized equilibrium is simply:

$$
u^{\prime}\left(c_{t}\right)=\beta E_{t} u^{\prime}\left(c_{t+1}\right)(1+r)
$$


Using (14) and (13), the Euler equation for consumption for the social planner becomes:

$$
\left.u^{\prime}\left(c_{t}\right)=\beta E_{t}\left[u^{\prime}\left(c_{t+1}\right)+\mu_{t+1}^{S P} \Psi_{t+1}\right)\right](1+r)
$$

Consider now a reallocation of wealth by the social planner starting from the privately optimal allocations in the decentralized equilibrium. In particular, consider the welfare effects of a reduction of one unit of debt. Because decentralized agents are at the optimum, (15) shows that the first order private welfare benefits $\beta E_{t} u^{\prime}\left(c_{t+1}\right)(1+r)$ are equal to the

first order private welfare losses $u^{\prime}\left(c_{t}\right)$ in the margin. Using (16), the social planner has a marginal cost of reducing debt equal to the private marginal cost but faces higher marginal benefits given by $\beta E_{t} u^{\prime}\left(c_{t+1}\right)(1+r)+\beta E_{t} \mu_{t+1}^{S P} \Psi_{t+1}(1+r)$. The second term of the last expression corresponds to the expectation on how an additional marginal unit of savings helps relax the credit constraint due to the debt-deflation channel when it becomes binding, a fact not internalized by the representative agent. This yields our externality result.

\section{Proposition 2 (Constrained Inefficiency)}

Assume the credit constraint binds in some state of nature in the decentralized equilibrium. Then, the decentralized equilibrium is not constrained Pareto optimum.

Proof: See appendix

\section{Solution Method and Calibration}

The previous section showed analytically that the decentralized equilibrium is constrained inefficient. In particular, it showed that the social shadow value of wealth exceeds the private shadow value of wealth during a crisis, hence a social planner has a higher incentive to save than an individual agent in the decentralized equilibrium when it is likely that the credit constraint will become binding in a future state of nature. In this section, we describe the solution method and the calibration used to evaluate the quantitative implications of the inefficiency. 


\subsection{Solution Method}

To solve for the social planner's problem, we use the algorithm described in Arellano and Mendoza (2003). This method is based on value function iteration and acknowledges that the credit constraint is only occasionally binding. ${ }^{11}$ The key difference between this method and the one necessary to solve for the decentralized equilibrium is that atomistic agents must take prices as given. We develop a method to solve for the recursive competitive equilibrium by employing a doubly nested fixed-point algorithm.

For any given belief of the evolution of aggregate bonds, there is an "inner" fixed-point algorithm that solves the Bellman equation. There is also an "outer" fixed-point algorithm that searches iteratively on a conjecture for the evolution of aggregate bonds that satisfies the rational expectations and market clearing conditions. Once the Bellman equation is solved, the actual law of motion $\hat{b}\left(B, B, y^{T}\right)$ can be derived. If this law of motion does not coincide with the perceived law of motion, a new trial is obtained and fed into the Bellman equation again.

The new trial is based on a Gauss-Seidel algorithm that assigns a decreasing weight to the effective law of motion. It is important to adjust slowly to the new conjecture since iterations on the perceived laws of motions do not follow a contraction mapping and may not converge due to the well-known problem of unstable "hog cycles." To obtain convergence in the outer fixed-point algorithm, it is also important to allow the agents in their optimization problem to choose a value of net foreign assets, which is outside the grid. The algorithm to solve for the decentralized equilibrium for any given values of parameters follows these steps:

1. Generate a discrete grid for the economy's asset and the shock state space.

2. Conjecture a law of motion for aggregate net foreign assets $B^{\prime}=\Gamma\left(B, y^{T}\right)$ at each point of the state space, which implies a price given by (10).

3. Solve for the policy functions $\left\{\hat{b}\left(b, B, y^{T}\right), \hat{c}^{T}\left(b, B, y^{T}\right), \hat{c}^{N}\left(b, B, y^{T}\right)\right\}$ via value function iteration the Bellman equation (11).

\footnotetext{
${ }^{11}$ Note that if we solve our model imposing an always binding credit constraint, it would not be possible to distinguish between the allocations of the decentralized equilibrium and the social planner.
} 
4. Using the decision rules in the previous step, calculate the effective law of motion of net foreign assets $\hat{b}\left(B, B, y^{T}\right)$ and evaluate the previous conjecture. If $\sup _{B, y^{T}} \| \hat{b}\left(B, B, y^{T}\right)-$ $\Gamma\left(B, y^{T}\right) \|<\epsilon$, the recursive competitive equilibrium is found. Otherwise, update $\Gamma\left(B, y^{T}\right)$ with a Gauss-Seidel algorithm and go to step 3.

The solution method is described in more detail in the appendix.

\subsection{Calibration}

The values assigned to all models' parameters are listed in Table 1. A period in the model represents a year. The baseline model uses data from Argentina, an example of an emerging market with a business cycle that has been studied extensively. The risk aversion and the world interest rate are typical parameters in DSGE-SOE models, and we set $\sigma=2$ and $r=4$ percent. $^{12}$

We assume that the endowment for tradables follows a $\log A R(1)$ process such that $\ln y_{t}^{T}=p \ln y_{t-1}^{T}+\varepsilon_{t}$ and $\varepsilon_{t} \sim N\left(0, \sigma_{\varepsilon}^{2}\right)$. This process is estimated using the annual sectorial data from the World Development Indicators (WDI) from 1965 to 2007, the longest time series available from official sources. We classify manufacturing industry and primary products as tradables, following the standard methodology. ${ }^{13}$ The estimation of the cyclical component of the tradable output process yields a standard deviation $\sigma_{y^{T}}=0.059$ and an autocorrelation coefficient $\rho=0.54 .^{14}$ We discretize the shock into a finite first-order Markov process with five grid points using the quadrature based procedure of Tauchen and Hussey (1991). ${ }^{15}$ The endowment of non-tradables $y^{N}$ is normalized to one without loss of generality.

The elasticity of substitution is an important parameter because it affects the magnitudes of the price adjustment. For a given reduction in tradable consumption, a higher elasticity implies a lower change in the price of non-tradables and therefore a weaker debt-deflation mechanism. As decentralized agents do not internalize the price effects, a higher elasticity would tend to reduce the externality. The range of estimations for the elasticity of substi-

\footnotetext{
${ }^{12}$ See e.g. Mendoza (1991), Neumeyer and Perri (2005) and Aguiar and Gopinath (2007).

${ }^{13}$ See for example Garcia (2008) and Mendoza and Terrones (2008).

${ }^{14}$ We de-trend the data with the HP filter with a parameter of 100 , the standard value for annual data.

${ }^{15}$ This results in an actual standard deviation and autocorrelation which are 99.8 percent of the true values.
} 
tution is between 0.40 and $0.83 .{ }^{16}$ As a conservative benchmark, we set $\mu$ such that the elasticity of substitution equals the upper bound of this range. ${ }^{17}$

The three remaining parameters are the discount factor $\beta$, the weight of tradable goods in the utility function $\omega$, and the credit constraint coefficient $\kappa$, which are set so that the long-run moments of the decentralized equilibrium match three historical moments of the data. The discount factor is set so that the average net foreign asset position-to-GDP ratio in the model equals its historical average in Argentina, which is equal to -29 percent in the dataset constructed by Lane and Milesi-Ferretti (2001). This calibration results in a value of $\beta=0.91$, a standard value for annual frequency.

The weight of tradable consumption in the CES aggregator $\omega$ is calibrated to match a share of tradable production of 32 percent. ${ }^{18}$ This approach is reasonable one to calibrate $\omega$ since manipulating (5) yields that the ratio of non-tradable-tradable GDP denoted by $\frac{p_{t}^{N} y^{N}}{y^{T}}$ equals $\left(\frac{1-\omega}{\omega}\right)\left(\frac{c_{t}^{T}}{c^{N}}\right)^{\eta}$. This calibration results in a value of $\omega$ of 0.31 , close to the values used in the literature. ${ }^{19}$

The parameter $\kappa$ is calibrated to match the observed frequency of "Sudden Stops" of Argentina, which is about 8.2 percent in Eichengreen, Gupta, and Mody (2006)'s data set. To be consistent with the Sudden Stops definition of Eichengreen et al. (2006), we define Sudden Stops in our model as events where the credit constraint binds and the increase in net capital outflows-to-GDP ratio exceeds one standard deviation. This calibration results in a value of $\kappa$ equal to 0.32 .

\section{Results of the Quantitative Analysis}

We now turn to report the significance of the credit externality by comparing the results from simulating the social planner's solution and the decentralized equilibrium solution. We are particularly interested in how the distortion introduced by the credit externality affects

\footnotetext{
${ }^{16}$ See Mendoza (2006), Lorenzo, Aboal, and Osimani (2005), Gonzalez and Neumeyer (2004) and Stockman and Tesar (1995).

${ }^{17}$ We then show in the sensitivity analysis how a lower elasticity of substitution can increase the distortions produced by the externality even more compared to the baseline scenario.

${ }^{18}$ Garcia(2008) reports an average share of tradables of 32 percent using almost a century of data from Argentina. The average share of tradables in the data used from WDI is also 32 percent for the period 1980-2006.

${ }^{19}$ For example, Durdu, Mendoza, and Terrones (2008) sets $\omega$ to 0.34 .
} 
Table 1: Parameter Values

\begin{tabular}{lll}
\hline & Value & Source \\
\hline Interest rate & $r=0.04$ & Standard value DSGE-SOE \\
Risk aversion & $\sigma=2$ & Standard value DSGE-SOE \\
Elasticity of substitution & $1 /(1+\eta)=0.83$ & Conservative value \\
Non-tradable endowment & $y^{N}=1$ & Normalization \\
Stochastic structure & $\sigma_{y^{T}}=0.059, \rho=0.54$ & Argentina's economy \\
\hline Calibration & Value & Target \\
\hline Discount factor & $\beta=0.91$ & Average NFA-GDP ratio $=-29 \%$ \\
Weight on tradables in CES & $\omega=0.31$ & Share of tradable output $=32 \%$ \\
Credit coefficient & $\kappa=0.32$ & Frequency of Sudden Stops $8.2 \%$ \\
\hline
\end{tabular}

the vulnerability to financial crises and the aggregate level of debt. We start by showing how the policy functions of the social planner and the decentralized equilibrium differ and then analyze the consequences for the long-run distribution of debt and for the probability and the severity of a financial crisis. To complete the quantitative analysis, we present a comparison of the simulation results to the data and an extensive sensitivity analysis.

\subsection{Policy Functions}

Figure 1 shows how the policy function for the social planner differs from the decentralized equilibrium policy function when the shock is one standard deviation below trend. ${ }^{20}$ Since the mean value of tradable output is 1 , we can interpret all results in terms of this variable. Without the endogenous borrowing constraint, the policy function for next period's net foreign assets would be monotonically increasing in current net foreign assets. However, when the actual model economy is hit by the negative shock while the credit constraint binds, a lower current net foreign asset position reduces the level of tradable consumption consistent with the credit constraint, thereby reducing the price of non-tradables. Because the credit constraint depends endogenously on the price of non-tradables, the credit constraint becomes tighter. Therefore, the economy displays a policy function for next period foreign assets that is decreasing in current foreign assets in the range for which the credit constraint binds.

In terms of Figure 1, this range corresponds approximately to a level of foreign assets lower than -0.94 for the social planner but lower than -0.93 for the decentralized equilibrium. ${ }^{21}$

\footnotetext{
${ }^{20}$ By policy function in the decentralized equilibrium, we refer to the equilibrium law of motion $\hat{b}\left(B, B, y^{T}\right)$.

${ }^{21}$ Unless otherwise noted, all figures are expressed as percentages of mean tradable output.
} 


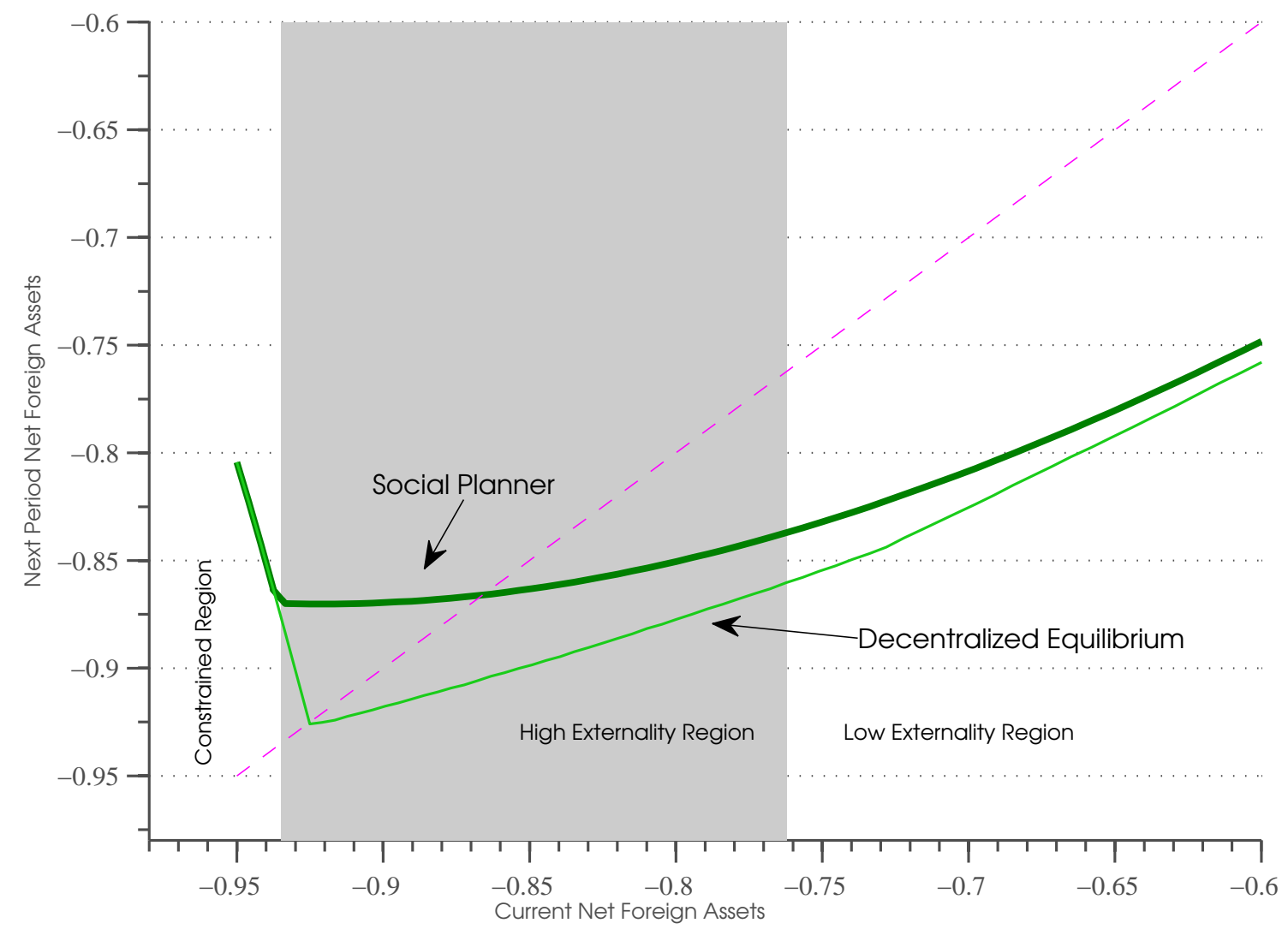

Figure 1: Policy Functions for Net Foreign Asset Position (tradable output = one-standard deviation below trend)

Because atomistic agents fail to internalize the price effects of their actions, they continue to borrow enough to trigger the binding credit constraint over some range of current assets, for which the social planner would choose a lower borrowing level that is monotonically increasing in current foreign assets.

We can distinguish three regions in Figure 1 according to the level of current net foreign assets: a "constrained region," a "high externality region", and a "low externality region." For low levels of net foreign assets, the allocations of future bonds coincide, since both the planner and the atomistic agents in the decentralized equilibrium choose the maximum they can borrow constituting the constrained area. At moderately higher current levels of net foreign assets, the economy is still highly leveraged, and a future financial crisis is relatively likely. Consequently, the social planner who internalizes that additional borrowing may result in amplification effects increases future net foreign assets relative to decentralized agents who take prices as given. This high externality region ends approximately when foreign assets 
reach -0.77. Finally, as net foreign assets increase further and the probability of a financial crisis becomes relatively low, the policy functions become similar to each other. Comparing the policy functions against the 45-degree line also shows that for relatively low current levels of bonds, the economy increases savings in response to a negative shock, resulting in capital outflows.

\subsection{Long-Run Distribution of Debt}

Figure 1 implies that the decentralized equilibrium will display higher levels of debt than what the social planner would command. In fact, Figure 2 shows how the ergodic distribution of net foreign assets for the decentralized equilibrium assigns higher probability to higher levels of debt. The shaded region in Figure 2 illustrates the mass of probability in the decentralized equilibrium's distribution allocated to high levels of debt that receive no probability in the social planner's distribution. While the maximum level of debt occurring with positive probability for the planner is approximately 0.91 , in the decentralized equilibrium the economy exceeds this level of debt about 80 percent of the time.

These results are critical for understanding why the credit externality makes the economy vulnerable to more frequent and more severe financial crises, as we will show below. A higher existing leverage requires a greater adjustment in tradable consumption to satisfy the credit constraint. $^{22}$ Consequently, Figure 2 shows that the social planner reduces the exposure to states in which the contraction in consumption needed to satisfy the credit constraint is large.

Because crises are a low probability events, the differences in the average level of debt are quite modest. In fact, the average Debt-to-GDP ratio is 29.2 percent for the private economy and 27.9 percent for the social planner. However, the maximum Debt-to-GDP ratio of the decentralized equilibrium exceeds the socially optimal by 14 percentage points of GDP. ${ }^{23}$

\footnotetext{
${ }^{22}$ To see this more clearly, suppose that at an initial level of debt, the constraint is satisfied with equality but is not binding. A higher initial debt requires a lower tradable consumption for the same choice of net foreign assets. But, a lower tradable consumption means a lower real exchange rate which means that the same choice of net foreign asset is not feasible. Therefore, higher leverage requires consumption to be reduced even more when the credit constraint binds.

${ }^{23}$ See table 5 in the appendix.
} 


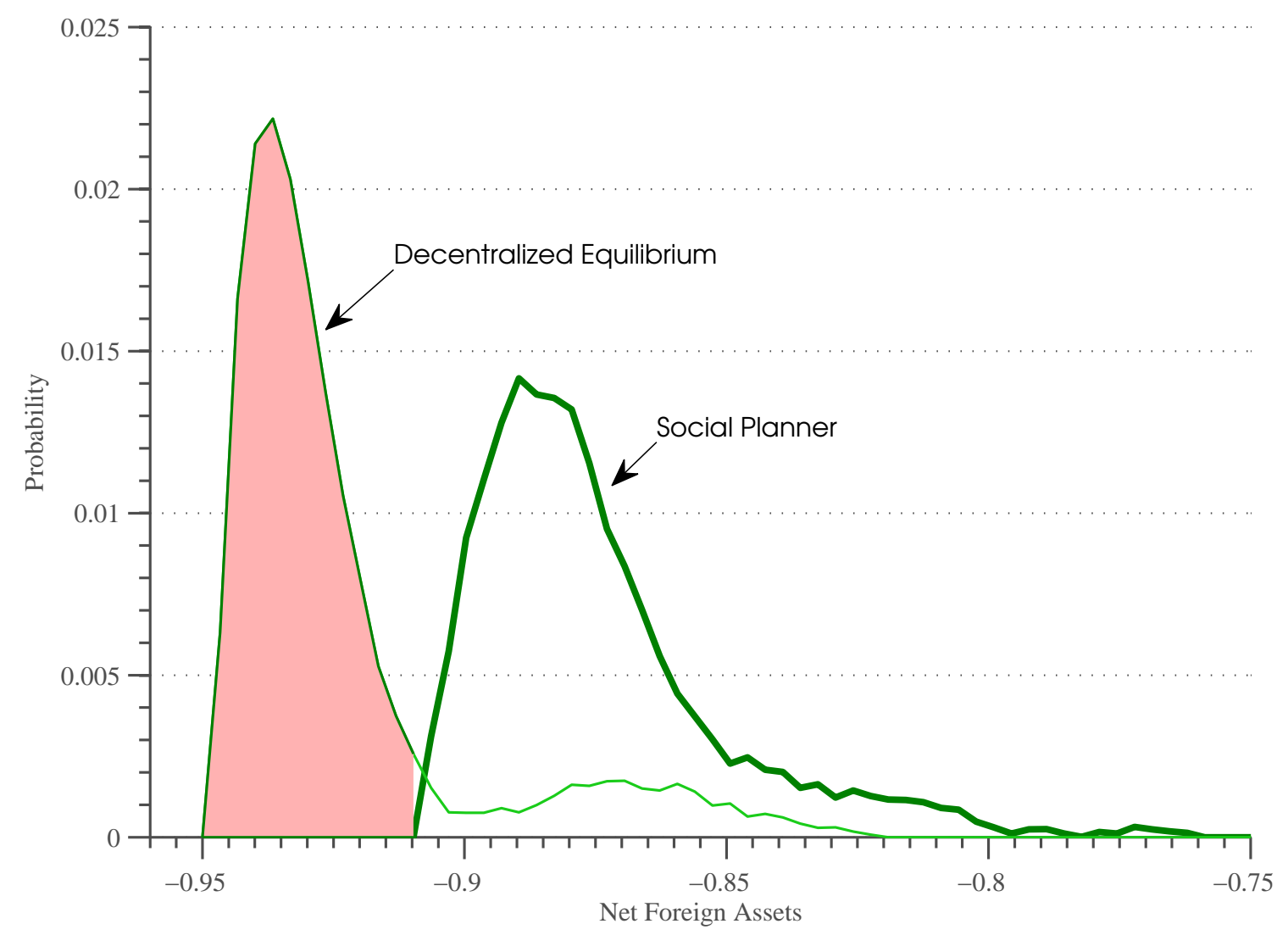

Figure 2: Ergodic Distribution of Net Foreign Assets. Note: The shaded region represents debt positions that have positive probability in the decentralized equilibrium and zero probability for the social planner.

\subsection{Financial Crises: Incidence and Severity}

In this section, we establish that overborrowing in the decentralized equilibrium leaves the economy vulnerable to more frequent and more severe financial crises, i.e. Sudden Stops. ${ }^{24}$ To demonstrate this result, we use the policy functions of the model to conduct an event analysis exercise. We perform a 50,000-period stochastic time series simulation of the social planner and the decentralized equilibrium's allocations and use the resulting artificial data to study the changes on impact during financial crises as defined above (i.e. periods in which the credit constraint becomes binding and the increase in the current account-GDP ratio exceeds one standard deviation $).^{25}$

\footnotetext{
${ }^{24}$ Since financial crises in our model take the form of Sudden Stops, we use these terms interchangeably.

${ }^{25} \mathrm{~A}$ binding credit constraint in our simulations may not always deliver capital outflows, consumption drops, and real exchange rate depreciation, although they conceptually increase the amplification relative to perfect capital markets. Therefore, we set as a threshold an increase in capital outflows equivalent to
} 
According to the simulation, the private economy's long-run probability of a financial crisis is more than seven times larger than the socially optimal (1.1 percent versus 8.2 percent). For chosen levels of debt higher than 0.85 , there is a positive probability in our simulations under both environments that a negative shock will trigger the credit constraint in the next period. Because the social planner reduces leverage relative to the private economy, the chances that a negative shock will trigger the credit constraint decreases. In fact, in the social planner's problem, financial crises occur with positive probability only if a negative shock that is larger than two standard deviations is realized. In contrast, the economy in the decentralized equilibrium has about a 23 percent chance of carrying a debt level such that a negative one-standard-deviation shock would cause a financial crisis.

The magnitudes of financial crises are substantially more severe because of the externality. Figure 3 shows how the long-run unconditional cumulative probability of consumption drops differs with and without the externality during financial crises. This figure shows how the decentralized equilibrium concentrates higher probability in the region with higher consumption drops. The maximum drop of consumption with positive probability is 24 percent for the decentralized equilibrium and 14 percent for the planner. Moreover, as Figure 3 shows, the decentralized equilibrium has a long-run probability of experiencing a drop in consumption higher than the maximum drop of consumption of the social planner of about 1.5 percent. This occurrence also means that about 19 percent of the crises of the decentralized equilibrium display a collapse in consumption that is higher than the maximum consumption drop in the social planner's crises. ${ }^{26}$

The drops in capital inflows and the real exchange rate during financial crises are also more pronounced because of the externality. In the decentralized equilibrium, capital outflows can reach a maximum of 25 percentage points of GDP (versus 11 percent in the social planner), and the real exchange rate can fall upto 49 percent (versus 33 percent in the social planner) relative to long run values.

one-standard-deviation of capital outflows in the decentralized equilibrium, which is consistent with the empirical literature. Our results are robust to alternative definitions of a crisis event.

${ }^{26}$ As crises occur only when the economy is hit by a shock larger than two standard deviations for the social planner, there is a set of relatively milder crises of the decentralized equilibrium that have zero probability for the social planner. For the same reason, the average change in consumption conditional on a financial crisis are still quite similar with and without the externality. 


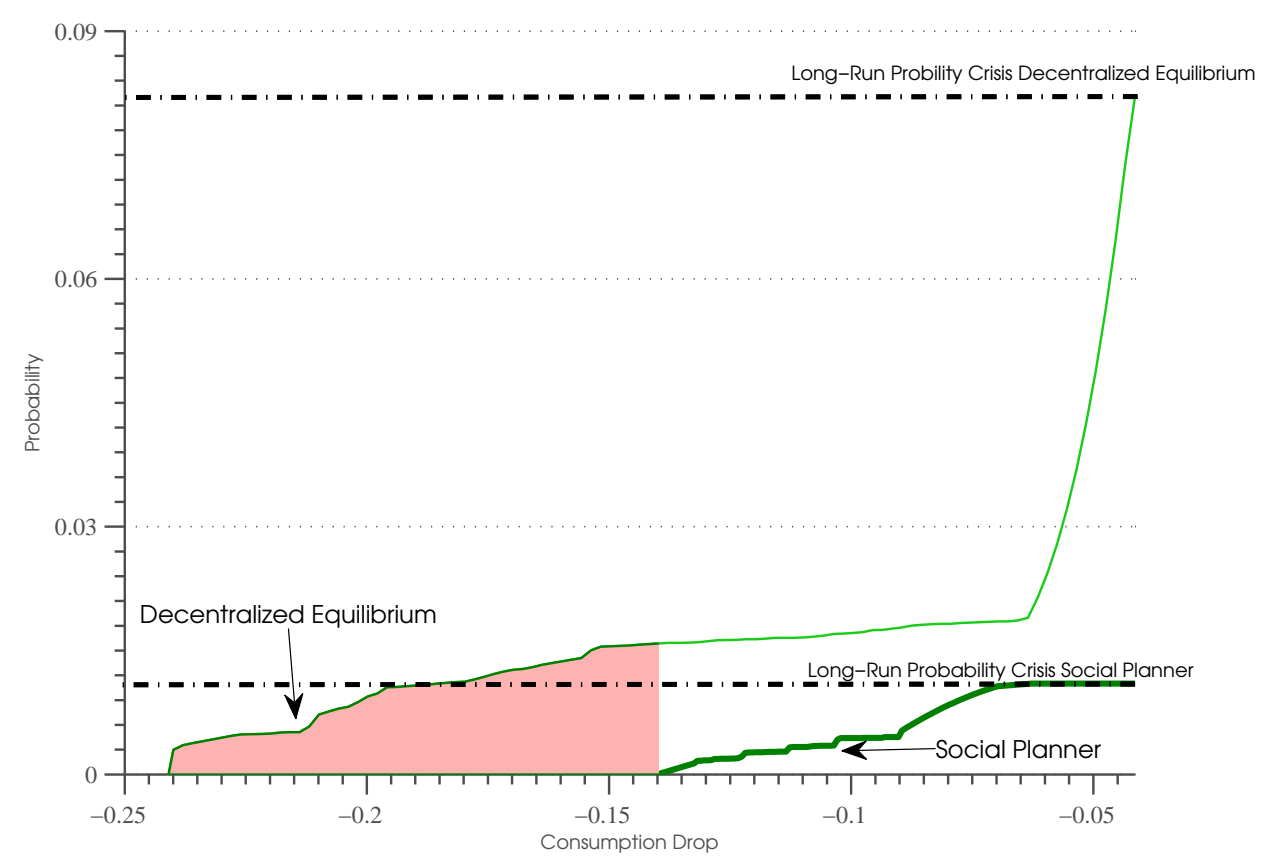

Figure 3: Unconditional CDF of Consumption Drops During Financial Crises.

Note: The shaded region represents consumption drops that have positive probability in the decentralized equilibrium and zero probability for the social planner.

The more frequent and the more severe financial crises that the decentralized economy experiences are a result of the fact that private agents take prices as given and fail to internalize that their additional borrowing results in amplification effects when negative income shocks trigger the credit constraint.

\subsection{Comparison to the Data}

The business cycle moments for emerging economies and the regularities of Sudden Stops are well documented, and the results obtained in this paper are consistent with previous studies. ${ }^{27}$ Table 6 shows the business cycle statistics computed for the decentralized equilibrium's simulation, and Table 2 reports the business cycle statistics for Argentina. To make the results comparable, we express both sets of moments in units of tradables. A comparison between these two sets of moments shows that the decentralized equilibrium succeeds at accounting for key business cycle regularities. Consumption is more volatile than output,

\footnotetext{
${ }^{27}$ See e.g. Neumeyer and Perri (2005) for general features and Calvo, Izquierdo, and Talvi (2006) for a focus on Sudden Stop events.
} 
displaying positive correlation with output and serial autocorrelation. Another feature of the model which is consistent with the data is that the current account is negatively correlated with output. This result is driven by the endogenous borrowing constraint, which becomes tighter during crises due to the real depreciation that erodes the ability to borrow. The magnitudes of Sudden Stops reported in the event analysis are also in the same orders of magnitudes of actual Sudden Stops as reported in Table 3.

Most of the long-run business cycle moments of the social planner and the decentralized equilibrium do not present substantial differences because the differences between the simulations are concentrated on relatively low probability events, i.e. when the credit constraint is binding. Still, in the decentralized equilibrium, capital inflows are more procylical and consumption is relatively more volatile.

\subsection{Sensitivity Analysis}

How does the magnitude of the externality change with different values assigned to the parameters? According to Proposition 1, the difference between the social shadow value of wealth and the private shadow value of wealth is given by the "externality term" $\mu_{t} \Psi_{t}$ where

$\Psi_{t}=\kappa \frac{1-\omega}{\omega}\left(\frac{c_{t}^{T}}{y^{N}}\right)^{\eta}(1+\eta)$. Therefore, changes in parameter values will affect the externality directly through $\Psi_{t}$ or through general equilibrium effects in the externality term.

Table 8 presents the results of the sensitivity analysis with respect to the elasticity of substitution parameter $\mu$, credit coefficient $\kappa$, risk aversion $\sigma$, standard deviation of tradable output $\sigma_{y^{T}}$, and the weight share of tradables in the utility function $\omega$. Overall, the sensitivity analysis suggests that the credit externality creates significant distortions for plausible parameterizations. We analyze here how the distortion changes with the elasticity of substitution between tradables and non-tradables and leave the rest of the analysis for the appendix.

As mentioned above, we chose as a conservative baseline an elasticity of substitution that is in the upper bound of the estimations. With a lower elasticity of substitution, a given decrease in consumption requires a greater adjustment in the real exchange rate to equilibrate the market. Because the social planner internalizes the price effects of individual actions, the distortion introduced by the externality increases with a lower elasticity of substitution. In 
fact, with an elasticity of substitution lower than 0.7 , the social planner does not experience financial crises while the decentralized equilibrium still experiences financial crises 2.3 percent of the time, and the severity of these episodes is even stronger.

Figure 4 shows how overborrowing changes with the elasticity of substitution. The y-axis indicates the difference between the maximum Debt-to-GDP ratio of the decentralized equilibrium and the maximum Debt-to-GDP ratio of the social planner. ${ }^{28}$ The differences in the probability of a financial crisis and the changes conditional on these episodes follow a similar pattern. When the elasticity of substitution is 0.4 , which is the lower bound of the estimations, excessive debt can reach 37 percentage points of GDP. The overborrowing decreases sharply as the social planner starts to experience financial crises with positive probability and then is reduced more gradually. While theoretically, the distortion is qualitatively present for any finite value of the elasticity, for values of the elasticity greater than 4 , the allocations of the social planner and the decentralized equilibrium become almost indistinguishable. ${ }^{29}$

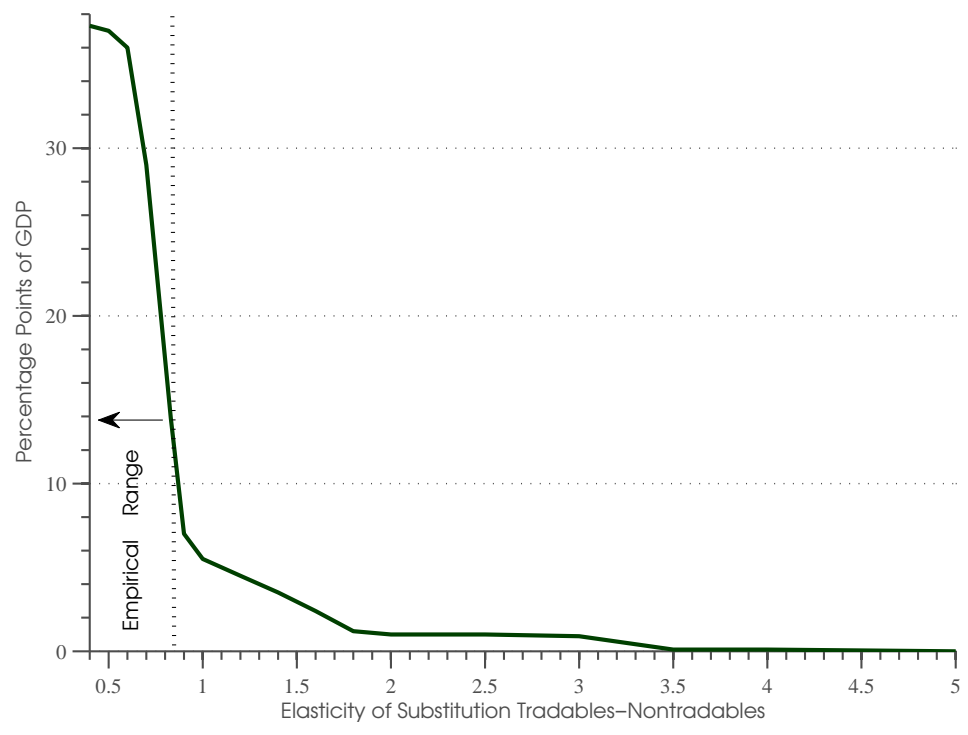

Figure 4: Sensitivity Analysis: Elasticity of Substitution and Overborrowing. Note: Overborrowing is measured as the difference between the maximum Debt-to-GDP ratio of the decentralized equilibrium and the maximum Debt-to-GDP ratio of the social planner.

\footnotetext{
${ }^{28}$ As explained above the average differences in the Debt-to-GDP ratio are smaller.

${ }^{29}$ For values of the elasticity of substitution above 5 , the probability of financial crises as well as the changes conditional on these episodes are the same when rounding these figures to the first decimal place.
} 


\section{Welfare and Policy Implications}

Theoretically, a wide range of policy measures can improve welfare relative to the laissezfaire equilibrium. First-best policy measures are necessary to address the root of the externality: the credit constraint. Examples of such policies are enhancing the enforcement of contracts and increasing transparency. Since it is practically impossible to eliminate all contractual frictions leading to credit constraints, it is desirable to study how we can improve the market equilibrium given those financial frictions.

We analyze how a tax on capital flows can correct the externality and deliver the constrained Pareto optimal allocation. Our focus on this instrument is justified by the fact that countries historically have used it with the goal of reducing financial vulnerabilities. 30,31 As Pigouvian taxation prescribes, the tax that needs to be charged induces households to internalize the externality by raising the private cost of debt to its socially efficient level. The following proposition summarizes our results:

\section{Proposition 3 (Optimal Policy)}

Let the social planner's solution be $\left\{c_{t}^{T}, c_{t}^{N}, b_{t}^{T}, p_{t}^{N}, \lambda_{t}^{S P}, \mu_{t}^{S P}\right\}_{t=0}^{t=\infty}$ and let the linear tax rate on debt at time $t$ and collected at time $t+1$ be:

$$
\tau_{t, t+1}^{*}= \begin{cases}(1+r) \frac{E_{t} \mu_{t+1}^{S P} \Psi_{t+1}}{E_{t} u_{T}(t+1)} & \text { if } \mu_{t}^{S P}=0 \\ 0 & \text { if } \mu_{t}^{S P}>0\end{cases}
$$

which is returned to households in the form of lump sum transfers $T_{t, t+1}=b_{t+1} \tau_{t, t+1}^{*}$. Then the social planner's allocations $\left\{c_{t}^{T}, c_{t}^{N}, b_{t}^{T}\right\}$, price $\left\{p_{t}^{N}\right\}$, and policies $\left\{\tau_{t, t+1}^{*}, T_{t, t+1}\right\}$ constitute a decentralized competitive equilibrium.

Proof: See appendix

The intuition for this expression is straightforward: (17) represents the non-internalized marginal cost of raising debt for the next period. If the constraint is triggered for the next

\footnotetext{
${ }^{30}$ Chile's experience with taxes on capital inflows is generally seen as successful, see Eichengreen and Fishlow (1998).

${ }^{31}$ Note that taxes on capital flows are also implemented as taxes on foreign debt so we use these terms interchangeably, see Gallego, Hernández, and Schmidt-Hebbel (1999) for empirical evidence.
} 
period, a marginal increase in debt requires a further tightening of the credit constraint of $\Psi_{t+1}$, which has a marginal utility cost of $\mu_{t+1}^{S P}$. The non-internalized marginal cost of raising debt is then given by the expected marginal utility cost of tightening the credit constraint $E_{t}(1+r) \mu_{t+1}^{S P} \Psi_{t+1}$, normalized by the expected marginal utility $E_{t} u_{T}(t+1)$. In this way, the tax rate tends to increase with the level of borrowing. ${ }^{32}$

How large must the tax be to correct the externality? Figure 5 shows the optimal tax rate when tradable output is one standard deviation below trend for different levels of current net foreign assets. There is a parallel between the effective tax rate and the three regions described in Figure 1. In the constrained region, when the crisis is already underway, a tax on borrowing is ineffective. In the high externality region, where decentralized agents take on a level of debt that leaves the economy vulnerable to a financial crisis, a tax must be imposed to discourage borrowing. The tax tends to increase with the initial debt since shadow value of relaxing the credit constraint is decreasing in the level of net foreign assets. Finally, in the low externality region, borrowing in the private economy is low enough to avoid future financial crises, and no tax is needed. On average, the effective tax rate is 4.5 percent.

The relation between the optimal tax and the business cycle is highly non-linear. In particular, taxes on debt are in relatively tranquil times to reduce the vulnerability to financial crisis. The optimal policy also reduces the procyclicality of capital flows as discussed above, which in Kaminsky, Reinhart, and Vegh (2004) is documented as an important regularity of emerging markets that make these countries financially more unstable. In broader terms, our analysis is a case for macro-prudential regulation (Borio, 2003).

It is worth noting that in general correcting the externality reduces the vulnerability to financial crises but does not rule them out in the long run. Because a constrained social planner cannot break Fisher's debt deflation mechanism, it is still socially optimal to experience a crisis in some unfortunate states of nature in a second best world. The trade-off of the optimal policy should be clear: by reducing leverage, the risk of a future financial crisis goes down, yet postponing consumption is not free. Our policy trade-off resembles the

\footnotetext{
${ }^{32}$ Note that at any point in time, the tax is not dependent on next period state of nature; therefore, the social planner is not effectively introducing new risk markets, see Stiglitz,1982.
} 


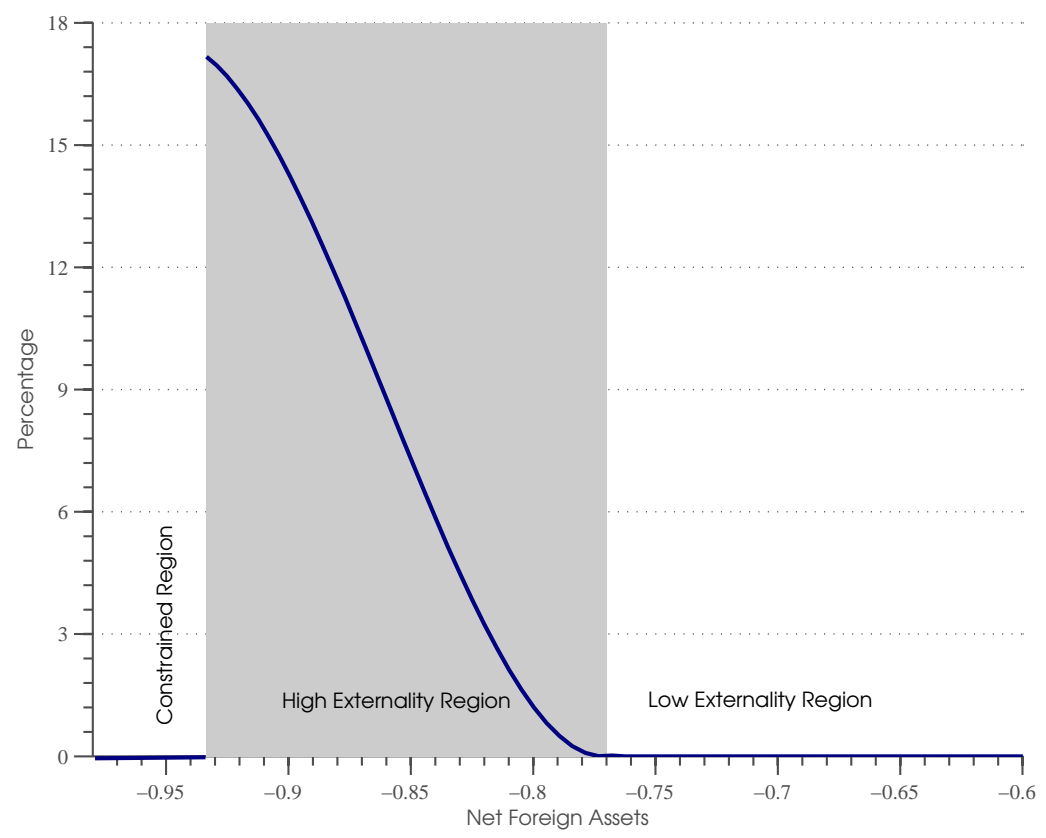

Figure 5: Optimal Tax Rate (tradable output = one-standard deviation below trend)

dilemma in Bordo and Jeanne (2002) about how optimal monetary policy should respond to a credit boom: preventing a credit boom reduces the probability of a future bust, but this prevention entails immediate costs in terms of output.

We now analyze the welfare gains associated with correcting the credit externality. It is well-known that the welfare cost of business cycles is typically small. Since the welfare gains from correcting the credit externality are associated with a smoother business cycle, the benefits from correcting the externality are also quite small. Following Lucas (1987), we first calculate the increase in consumption across all states of nature in the decentralized equilibrium necessary to make a consumer indifferent between living in the decentralized equilibrium (without government intervention) and correcting the externality starting at a particular state. Formally, for an initial state $(b, y)$, the welfare gain is $\gamma$ such that:

$$
E_{0} \sum_{t=0}^{\infty} \beta^{t} u\left(c_{t}^{D E}(1+\gamma)\right)=E_{0} \sum_{t=0}^{\infty} \beta^{t} u\left(c_{t}^{S P}\right)
$$

where $c_{t}^{D E}$ is the agent's consumption in the decentralized equilibrium and $c_{t}^{S P}$ is the agent's consumption in the social planner when starting at an initial state $(b, y) .{ }^{33}$

\footnotetext{
${ }^{33}$ Because of the homotheticity of the utility function, (18) can be written as: $(1+\gamma(b, y))^{1-\sigma} V^{D E}(b, y)=$
} 
For a given initial negative shock, the welfare gains displays a hump shape; Figure 6 shows the welfare gains of correcting the externality when tradable output is one standard deviation below the mean. For high values of leverage, the economy already is constrained so the welfare gains that result from correcting the externality occur in the distant future. At higher levels of current foreign assets, the economy is vulnerable to a financial crisis in the next period. Since the social planner acts in a precautionary way, the welfare gains from correcting the externality increase. Finally, in the low externality region, financial crises become less likely and the present discounted value of correcting the externality is reduced.

On average the welfare gains from correcting the externality are approximately 0.1 percent of permanent consumption. Even if the optimal policy does not introduce additional securities that partially complete the market, the welfare gains are larger than the benefits from introducing asset price guarantees (Durdu and Mendoza, 2006) or the benefits from introducing indexed bonds (Durdu, 2009), often suggested as policies to address Sudden Stops (Caballero, 2002). We see these welfare gains of correcting the externality only as a lower bound. First, we take as given the supply side of the economy. If a financial crisis affects for example the access of firms to working capital, it is likely that more severe financial crises as a result of the externality will produce output effects, therefore delivering higher welfare costs. Second, the risk we have considered is only aggregate; Chatterjee and Corbae (2007) shows that the welfare gains of eliminating the possibility of a crisis state can be as large as 7 percent of permanent consumption when considering idiosyncratic risk.

Our welfare analysis provides insights on how the benefits of the introduction of new financial regulation can be linked to the business cycle. Debate is ongoing among policy-makers on the right timing to introduce financial regulation. Often a concern is that introducing financial regulation during the early stages of a financial crisis can cause this regulation to be counterproductive. The results in this paper suggest that financial reform may deliver the maximum benefits as financial crises become relatively likely.

In the context of the debate of financial globalization desirability, Mishkin (2006) among others argues that domestic financial development is necessary to reap the benefits of finan$\overline{V^{S P}(b, y)}$ 


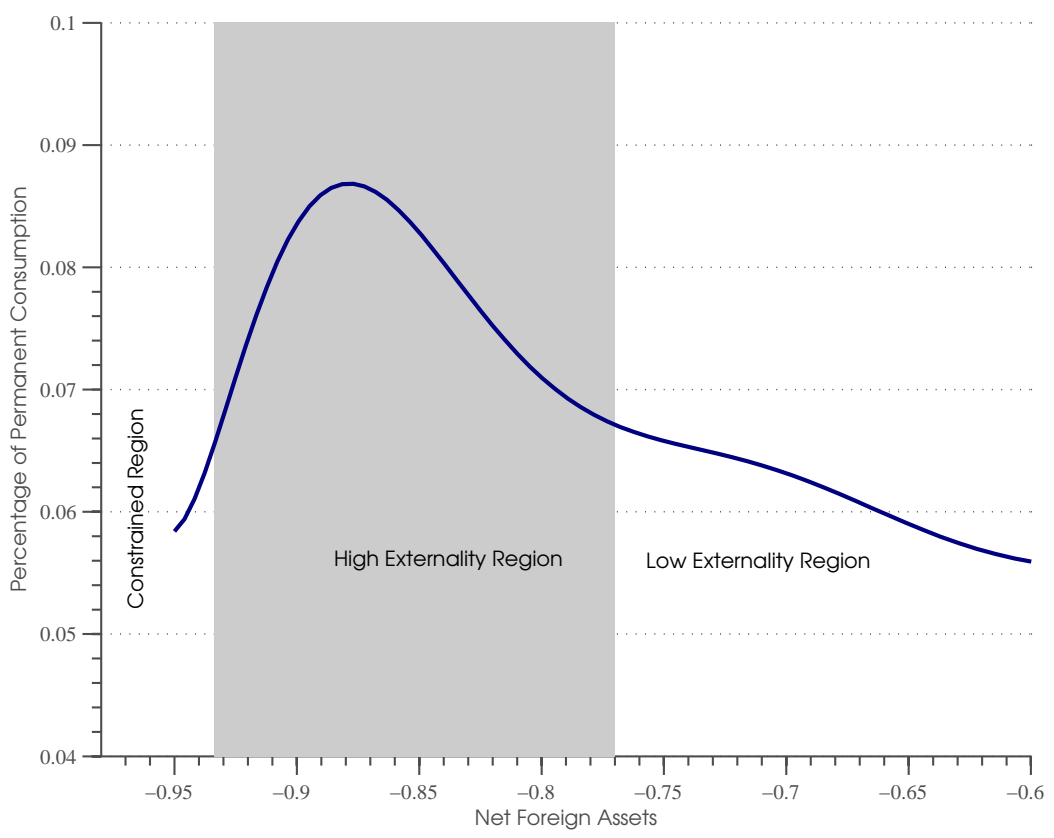

Figure 6: Welfare Gains from Correcting the Externality (tradable output = one-standard deviation below trend)

cial globalization. ${ }^{34}$ Our analysis suggests that when financial development is incomplete, countries should integrate with the global financial market but impose a tax on capital inflows to reduce their vulnerability to financial crises. In the long term, however, by improving the contractual environment of credit markets, countries that address the underlying root of the externality, i.e. the credit constraint, could obtain higher welfare gains.

Our rationale for taxing debt differs from the argument that agents fail to internalize how their private debt levels increase the country's average cost of funds because of monopoly power in the financial market. ${ }^{35}$ Tobin (2003) also proposed a tax on capital flows, but he claimed it was beneficial solely on the grounds that it reduced volatility per se. In our model, our policy measure is justified as a response to a well-specified externality. Our results complement Korinek (2008), who uses a three-period model to illustrate how taxing securities that deliver capital outflows in constrained states can be optimal. While the regulation target in Korinek (2008) is to alter the financial structure of a given amount of debt, our regulation target is to reduce the absolute level of debt.

\footnotetext{
${ }^{34}$ See also Edwards (1999), Mendoza, Quadrini, and Rios-Rull (2007)

${ }^{35}$ See Harberger (1985) and Bardhan (1967).
} 


\section{Conclusions}

This paper examined how credit constraints that link a private agent's debt to prices create a credit externality that magnifies the incidence and the severity of financial crises. When a negative shock triggers the credit constraint, agents are forced to cut consumption, which reduces the price of non-tradables and erodes collateral backed by non-tradables income. This action in turn leads to a further decrease in consumption, tightening credit constraints even further. Consequently, the economy plunges into a downward spiral where the drops in consumption, real exchange rate, and value of collateral mutually reinforce each other. Although agents are fully rational, they fail to internalize how additional borrowing results in these adverse debt-deflation amplification effects when negative shocks trigger the credit constraint. By reducing the amount of debt ex-ante, a social planner can mitigate the downward spiral in the real exchange rate during a crisis and make all agents better off.

In our calibrated model, we find that the credit externality increases more than seven times the long-run probability of a financial crisis (from 1.1 percent to 8.2 percent) and causes the maximum drop in consumption to increase by 10 percentage points in these episodes (from 14 percent to 24 percent). On the normative side, we have shown that a tax on debt can implement the constrained social optimum. The tax should be charged in relatively tranquil times to discourage leverage and decrease the vulnerability to financial crises. Our sensitivity analysis also sheds some light on the kinds of parameters which are likely to be relevant for the size in the distortion. In particular, the elasticity of substitution between tradable and non-tradable goods is the key parameter that drives the size in the distortion. These conclusions are obtained in the context of a two-sector DSGE-SOE model with occasionally binding endogenous credit constraints and an event analysis of financial crises that compares the time series of the economy with and without the credit externality.

Although our financial accelerator stems from a feedback loop between the real exchange rate and output, our results suggest that pecuniary externalities are likely to play an important role for closed economy macroeconomic models as well. A similar mechanism linking asset pricing and economic activity offers promising results to account for the fluctuations observed in the current global financial crises. Another interesting extension of this frame- 
work is the study of a setup with an explicit role for financial intermediation. This aspect is important to consider in light of the fact that financial intermediaries have played a key role in disrupting the flow of funds between lenders and borrowers during the recent U.S. financial crisis. Recently, studies like Gertler and Karadi (2009) have investigated how credit intervention can support credit flows when financial intermediaries face endogenous balance sheet constraints. The findings of this paper suggest that it would also be interesting to explore whether tighter capital requirements during tranquil times can improve welfare by raising the costs of leverage to the social value and reducing the likelihood of a financial crisis. Given the significant costs of financial crises, the further study of these issues seems of special value. 


\section{References}

Aguiar, M., and G. Gopinath (2007): "Emerging market business cycles: the cycle is the trend," Journal of Political Economy, 115(1), 69-102.

AiYAGARI, S. (1994): "Uninsured idiosyncratic risk and aggregate saving," The Quarterly Journal of Economics, pp. 659-684.

Aiyagari, S., and M. Gertler (1999): "Overreaction of Asset Prices in General Equilibrium," Review of Economic Dynamics, 2(1), 3-35.

Arellano, C., And E. G. Mendoza (2003): "Credit frictions and Sudden Stops in small open economies: an equilibrium business cycle framework for emerging market crises," in Dynamic Macroeconomic Analysis: Theory and Policy in General Equilibrium, ed. by C. N. Sumru Altug, Jagjit S. Chadha. Cambridge University Press.

Bardhan, P. (1967): "Optimum foreign borrowing," in Essays on the Theory of Optimal Economic Growth. MIT Press, Cambridge, MA.

Benigno, G., H. Chen, C. Otrok, A. Rebucci, and E. Young (2009): "Optimal Stabilization Policy in a Model with Endogenous Sudden Stops," Unpublished Manuscript. Bernanke, B., And M. Gertler (1989): "Agency costs, net worth, and business fluctuations," The American Economic Review, pp. 14-31.

Bernanke, B., M. Gertler, and S. Gilchrist (1999): "The financial accelerator in a quantitative business cycle model," in Handbook of Macroeconomics, ed. by J. Taylor, and M. Woodford, vol. 1C. by North-Holland.

Bhagwati, J. (2004): In defense of globalization. Oxford University Press, USA.

Bordo, M., And O. Jeanne (2002): "Monetary Policy and Asset Prices: Does Benign Neglect Make Sense?," International Finance, 5(2), 139-164.

Borio, C. (2003): "Towards a macroprudential framework for financial supervision and regulation?," CESifo Economic Studies, 49(2), 181-215.

Caballero, R. (2002): "Coping with Chiles external vulnerability: a financial problem," Economic Growth: Sources, Trends, and Cycles, pp. 377-416.

Caballero, R. J., and A. Krishnamurthy (2001): "International and domestic collateral constraints in a model of emerging market crises," Journal of Monetary Economics, 
Volume 48, Issue 3, December 2001, 513-548.

Calvo, G., A. Izquierdo, and R. Loo-Kung (2006): "Relative price volatility under Sudden Stops: The relevance of balance sheet effects," Journal of International Economics, $69(1), 231-254$.

Calvo, G. A., A. Izquierdo, and E. Talvi (2006): "Phoenix Miracles in Emerging Markets: Recovering without Credit from Systemic Financial Crises," The American Economic Review, Vol. 96, No. 2 (May, 2006),, 405-410.

Chamberlain, G., and C. Wilson (2000): "Optimal intertemporal consumption under uncertainty," Review of Economic Dynamics, 3(3), 365-395.

Chatterjee, S., And D. Corbae (2007): "On the aggregate welfare cost of Great Depression unemployment," Journal of Monetary Economics, 54(6), 1529-1544.

Chow, C., And J. Tsitsiklis (1991): "An optimal one-way multigrid algorithm for discrete-time stochasticcontrol," IEEE Transactions on Automatic Control, 36(8), 898-914. Christiano, L., C. Gust, and J. Roldos (2004): "Monetary policy in a financial crisis," Journal of Economic Theory, 119, 64-103.

DiAmond, P. (1967): "The role of a stock market in a general equilibrium model with technological uncertainty," The American Economic Review, pp. 759-776.

Durdu, B., E. G. Mendoza, and M. E. Terrones (2008): "Precautionary demand for foreign assets in Sudden Stop economies: An assessment of the New Mercantilism," Journal of Development Economics, forthcoming.

Durdu, C. (2009): "Quantitative implications of indexed bonds in small open economies," Journal of Economic Dynamics and Control, 33(4), 883-902.

Durdu, C., And E. Mendoza (2006): "Are asset price guarantees useful for preventing Sudden Stops?: A quantitative investigation of the globalization hazard-moral hazard tradeoff," Journal of International Economics, 69(1), 84-119.

Edwards, S. (1999): "How effective are capital controls?," The Journal of Economic Perspectives, pp. 65-84.

Eichengreen, B., And A. Fishlow (1998): "Contending with capital flows: what is different about the 1990s?," in Capital flows and financial crises. Cornell University Press. Eichengreen, B., P. Gupta, and A. Mody (2006): "Sudden Stops and IMF-Supported 
Programs," Discussion paper, National Bureau of Economic Research.

Farhi, E., M. Golosov, and A. Tsyvinski (2009): "A Theory of Liquidity and Regulation of Financial Intermediation," Review of Economic Studies, 76(3), 973-992.

Fisher, I. (1933): "The debt-deflation theory of great depressions," Econometrica, pp. $337-357$.

Gallego, F., L. Hernández, and K. Schmidt-Hebbel (1999): Capital controls in Chile: effective? efficient? Banco Central de Chile.

Garcia, J. (2008): "What Drives the Roller Coaster? Sources of Fluctuations in Emerging Countries," Mimeo, Duke University.

Geneakoplos, J., And H. Polemarchakis (1986): "Existence, regularity, and constrained suboptimality of competitive portfolio allocations when asset markets are incomplete," in Equilibrium Analysis, Essays in Honor of K. Arrow (W. Heller, R. Starr, and D. Starret, Eds.), Vol. III, Chap. 3,. Cambridge Univ. Press, Cambridge, 1986.

Gertler, M., S. Gilchrist, and F. Natalucci (2007): "External constraints on monetary policy and the financial accelerator," Journal of Money Credit and Banking.

Gertler, M., and P. Karadi (2009): "A Model of Unconventional Monetary Policy," Mimeo, NYU.

Gonzales-Rozada, M., And A. Neumeyer (2003): "The Elasticity of Substitution in Demand for Non-tradable Goods in Latin America. Case Study: Argentina," Discussion paper, mimeo, Inter-American Development Bank.

Guidotti, P., F. Sturzenegger, A. Villar, J. de Gregorio, and I. Goldfajn (2004): "On the Consequences of Sudden Stops [with Comments]," Economia, pp. 171-214. Harberger, A. (1985): "Lessons for debtor-country managers and policymakers," International Debt and the Developing Countries, pp. 236-57.

HugGett, M. (1993): "The risk-free rate in heterogeneous-agent incomplete-insurance economies," Journal of Economic Dynamics and Control, 17(5/6), 953-970.

Kaminsky, G. L., C. M. Reinhart, and C. A. Vegh (2004): "When it Rains, it Pours: Procyclical Capital Flows and Macroeconomic Policies," Working Paper 10780, National Bureau of Economic Research.

Kiyotaki, N., and J. Moore (1997): "Credit Cycles," Journal of Political Economy, 105, 
$211-248$.

KorineK, A. (2008): "Regulating Capital Flows to Emerging Markets: An Externality View," Mimeo, University of Maryland.

(2009a): "Excessive dollar borrowing in emerging markets: Balance sheet effects and macroeconomic externalities," Mimeo, University of Maryland.

(2009b): "Systemic Risk-Taking: Accelerator Effects, Externalities, and Regulatory," Mimeo, University of Maryland.

Lane, P., and G. Milesi-Ferretti (2001): "The external wealth of nations: measures of foreign assets and liabilities for industrial and developing countries," Journal of international Economics, 55(2), 263-294.

LJungqvist, L., And T. SARGEnT (2004): Recursive macroeconomic theory. MIT press.

Lorenzo, F., D. Aboal, and R. Osimani (2005): "The elasticity of substitution in demand for non-tradable goods in Uruguay," mimeo, Inter-American Development Bank, Latin American Research Network.

Lorenzoni, G. (2008): "Inefficient Credit Booms," Review of Economic Studies, 75, 809833.

LuCAs, R. (1987): Models of business cycles. Basil Blackwell New York.

McKinnon, R., And H. Pill (1996): "Credible liberalizations and international capital flows: the overborrowing syndrome," Financial deregulation and integration in East Asia.

MendozA, E. G. (1991): "Real business cycles in a small-open economy," American Economic Review, 81, 797-818.

— (2002): "Credit, Prices, and Crashes: Business Cycles with a Sudden Stop," in Preventing Currency Crises in Emerging Markets. Frankel, Jeffrey and Sebastian Edwards eds. Chicago: University of Chicago Press.

(2006): "Real Exchange Rate Volatility and the Price of Nontradables in SuddenStop-Prone Economies," Economia, fall, 103148.

— (2008): "Sudden Stops, Financial Crises and Leverage: A Fisherian Deflation of Tobin's Q," Working Paper 14444, National Bureau of Economic Research.

Mendoza, E. G., V. Quadrini, and V. Rios-Rull (2007): "On the Welfare Implications of Financial Globalization without Financial Development," Working Paper 13412, National 
Bureau of Economic Research.

Mendoza, E. G., and M. E. Terrones (2008): "An Anatomy Of Credit Booms: Evidence From Macro Aggregates And Micro Data," Working Paper 14049, National Bureau of Economic Research.

Mishkin, F. (2006): The next great globalization. Princeton University Press.

Neumeyer, P., And F. Perri (2005): "Business cycles in emerging economies: the role of interest rates," Journal of Monetary Economics, 52(2), 345-380.

Schmitt-Grohe, S., And M. Uribe (2003): "Closing small open economies," Journal of International Economics, 61, 163-185.

Schneider, M., And A. Tornell (2004): "Balance sheet effects, bailout guarantees and financial crises," Review of Economic Studies, pp. 883-913.

Stiglitz, J. E. (1982): "The inefficiency of the stock market equilibrium," The Review of Economic Studies, pp. 241-261.

- (2002): Globalization and Discontents. W.W. Norton, New York and London.

Stiglitz, J. E., And A. Weiss (1981): "Credit Rationing in Markets with Imperfect Information," American Economic Review, 71(3), 393-410.

Stockman, A., And L. Tesar (1995): "Tastes and technology in a two-country model of the business cycle: explaining international comovements," The American Economic Review, pp. $168-185$.

Tauchen, G., And R. Hussey (1991): "Quadrature-Based Methods for Obtaining Approximate Solutions to Nonlinear Asset Pricing Models," Econometrica, 59, 371-396.

Tobin, J. (2003): "A proposal for monetary reform," Eastern Economic Journal, 29(4), $519-526$.

Uribe, M. (2006): "On Overborrowing," American Economic Review Papers and Proceedings, 96, 417-421. 
Table 2: Argentina-Business Cycle Statistics

\begin{tabular}{lcccc}
\hline & $\begin{array}{c}\text { standard } \\
\text { deviation } \\
\text { in percent }\end{array}$ & $\begin{array}{c}\text { standard } \\
\text { deviation } \\
\text { relative to GDP }\end{array}$ & $\begin{array}{c}\text { correlation } \\
\text { with } \\
\text { GDP }\end{array}$ & $\begin{array}{c}\text { first-order } \\
\text { autocorrelation }\end{array}$ \\
\hline GDP & 15.3 & 1.00 & 1.00 & 0.61 \\
Consumption & 15.5 & 1.02 & 0.97 & 0.51 \\
Trade Balance-GDP ratio & 3.3 & 0.22 & -0.74 & 0.67 \\
Current Account-GDP ratio & 4.4 & 0.29 & -0.82 & 0.68 \\
Real Exchange Rate & 27.4 & 1.79 & 0.80 & 0.41 \\
\hline
\end{tabular}

Note: Annual data from International Financial Statistics (IFS), World Economic Outlook (WEO) and World Development Indicators (WDI) for the period 1980-2007. Consumption and GDP are deflated using the price index of tradable goods obtained from WDI, logged and detrended using a Hodrick Prescott filter with a smoothing parameter 100. The Real exchange rate is calculated using the IMF definition $\left(R E R_{i}=N E R_{i} \times C P I_{i} / C P I_{U S}\right.$ for country i). Standard Deviations of consumption and real exchange rate are expressed in percentage of the mean.

Table 3: Sudden Stop Events

(percental changes on impact relative to previous year)

\begin{tabular}{lccccc}
\hline Variable & Argentina 2001 & Argentina 1990 & Ecuador 1999 & Turkey 1994 & Mexico 1994 \\
\hline Current Account & 10.3 & 4.9 & 14.5 & 5.6 & 6.5 \\
Consumption & -22.3 & -11.7 & -5.6 & -4.5 & -6.4 \\
Real Exchange Rate & -57.6 & -37.3 & -31.2 & -25.4 & -31.0 \\
Output & -15.1 & -7.5 & -6.3 & -4.5 & -5.8 \\
\hline
\end{tabular}

Note: Own calculations based on data from IFS and WEO. The change in the current account is measured in percentage points of GDP.

Table 4: Severity of Financial Crises

(maximum changes during financial crises in percent of long run values)

\begin{tabular}{lcc}
\hline Crises Statistic & Decentralized Equilibrium & Social Planner \\
\hline Current Account & 25.1 & 11.2 \\
Consumption & -24.1 & -14.3 \\
Real exchange Rate & -49.5 & -32.7 \\
\hline
\end{tabular}

Note: Financial Crises are defined as events where the credit constraint binds and the current account-GDP ratio increases more than one standard deviation. . 
Table 5: Debt Levels

\begin{tabular}{lcc}
\hline & $\begin{array}{c}\text { Decentralized Equilibrium } \\
\text { (in percent) }\end{array}$ & $\begin{array}{c}\text { Social Planner } \\
\text { (in percent) }\end{array}$ \\
\hline Mean Debt-to-tradable output & 91.5 & 88.0 \\
Mean Debt-to-GDP & 29.2 & 27.9 \\
Maximum Debt-to-GDP & 57.3 & 43.5 \\
\hline
\end{tabular}

Table 6: Decentralized Equilibrium - Long Run Business Cycle Moments

\begin{tabular}{lcccc}
\hline & $\begin{array}{c}\text { standard } \\
\text { deviation } \\
\text { in percent }\end{array}$ & $\begin{array}{c}\text { standard } \\
\text { deviation } \\
\text { relative to GDP }\end{array}$ & $\begin{array}{c}\text { correlation } \\
\text { with } \\
\text { GDP }\end{array}$ & $\begin{array}{c}\text { first-order } \\
\text { autocorrelation }\end{array}$ \\
\hline GDP & 8.9 & 1.00 & 1.00 & 0.21 \\
Consumption & 10.4 & 1.16 & 0.99 & 0.10 \\
Trade Balance-GDP ratio & 2.8 & 0.31 & -0.71 & -0.21 \\
Current Account-GDP ratio & 2.7 & 0.30 & -0.69 & -0.21 \\
Real Exchange Rate & 7.9 & 0.88 & 0.99 & 0.08 \\
\hline
\end{tabular}

Note: Standard Deviations of consumption and real exchange rate are expressed in percentage of the mean.

Table 7: Social Planner - Long Run Business Cycle Moments

\begin{tabular}{lcccc}
\hline & $\begin{array}{r}\text { standard } \\
\text { deviation } \\
\text { in percent }\end{array}$ & $\begin{array}{c}\text { standard } \\
\text { deviation } \\
\text { relative to GDP }\end{array}$ & $\begin{array}{c}\text { correlation } \\
\text { with } \\
\text { GDP }\end{array}$ & $\begin{array}{c}\text { first-order } \\
\text { autocorrelation }\end{array}$ \\
\hline GDP & 7.5 & 1.00 & 1.00 & 0.42 \\
Consumption & 7.9 & 1.06 & 0.99 & 0.36 \\
Trade Balance-GDP ratio & 1.0 & 0.13 & -0.54 & -0.24 \\
Current Account-GDP ratio & 0.9 & 0.12 & -0.48 & -0.25 \\
Real Exchange Rate & 5.9 & 0.79 & 1.00 & 0.34 \\
\hline
\end{tabular}

Note: Standard Deviations of consumption and real exchange rate are expressed in percentage of the mean. 


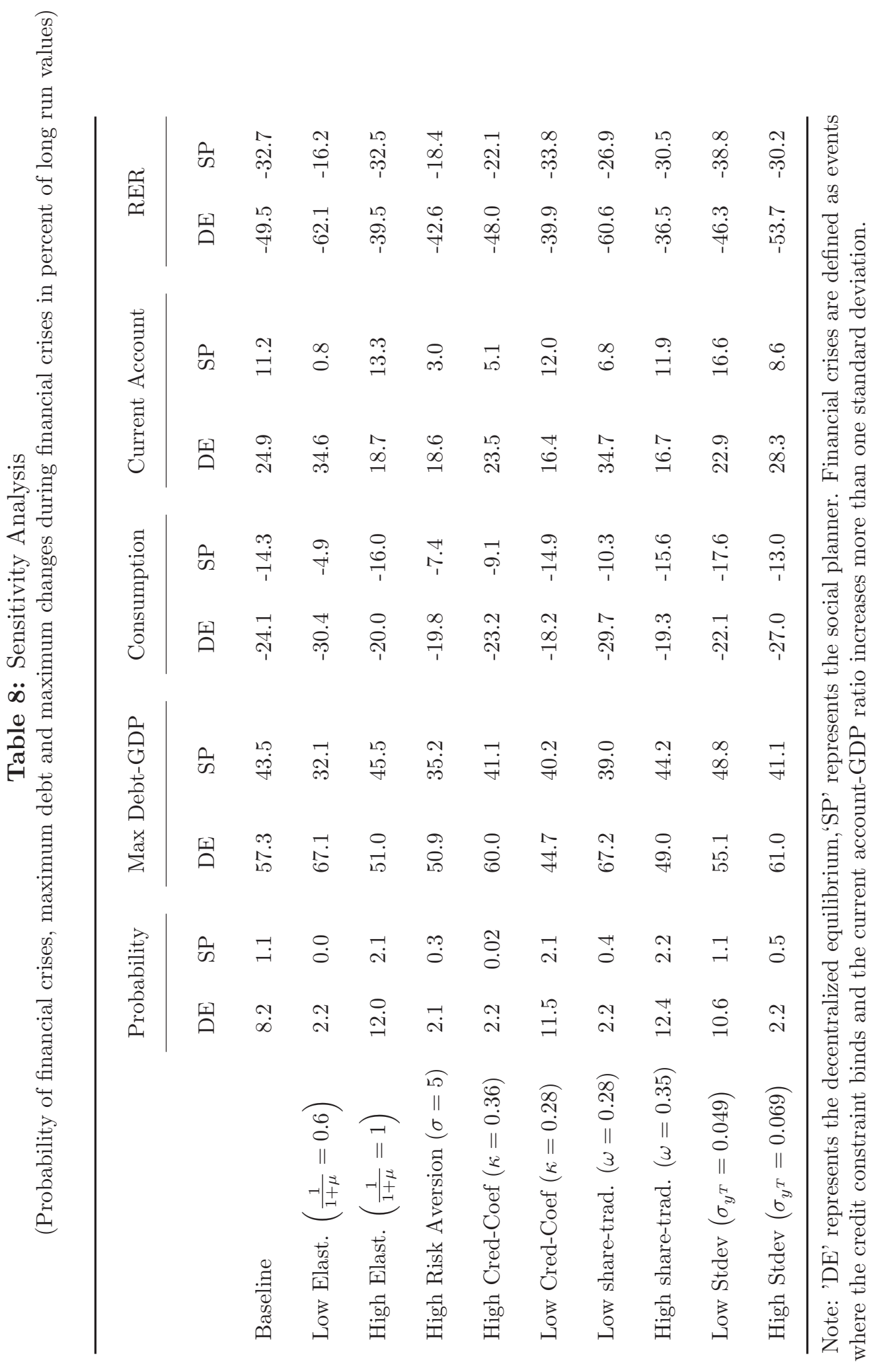




\section{Appendix A}

\section{A.1. Proof of Proposition 1 (Constrained Inefficiency)}

This is a proof by contradiction. Suppose the decentralized equilibrium is constrained Pareto optimum. Then, we can combine (4) and (13), yielding:

$$
\lambda_{t}^{D E}=\lambda_{t}^{S P}+\mu_{t}^{S P} \Psi_{t}
$$

where we denote with superscript 'SP' the multipliers of the social planner and with 'DE' those of the decentralized equilibrium. Updating this equation one period forward and taking conditional expectations at time $t$ :

$$
E_{t} \lambda_{t+1}^{D E}=E_{t} \lambda_{t+1}^{S P}+E_{t} \mu_{t+1}^{S P} \Psi_{t+1}
$$

Suppose that at time $t$, the borrowing constraint does not bind. Combining (6) and (14) we obtain:

$$
E_{t} \lambda_{t+1}^{D E}=E_{t} \lambda_{t+1}^{S P}
$$

Because at time $t+1$, the borrowing constraint binds with positive probability, then comparing (21) and (20) yields a contradiction.

\section{A.2. Proof of Proposition 2 (Optimal Tax)}

When a tax is placed on borrowing in the decentralized equilibrium, the only first order condition that changes is the Euler intertemporal condition (6) that becomes

$$
\lambda_{t}^{D E}=\beta E_{t} \lambda_{t+1}^{D E}\left(1+r+\tau_{t, t+1}\right)+\mu_{t}^{D E}
$$

Combining the optimality conditions for the social planner (13) and (14) yields:

$$
\frac{u_{T}(t)}{\beta E u_{T}(t+1)}=(1+r)+(1+r) \frac{\left.E_{t}\left[\mu_{t+1}^{S P} \Psi_{t+1}\right)\right]}{E_{t} u_{T}(t+1)}+\frac{\mu_{t}\left(1-\Psi_{t}\right)}{E_{t} u_{T}^{S P}(t+1)}
$$

When the constraint binds for the social planner, it also binds for the decentralized equilibrium and allocations coincide. If the constraint does not bind, it follows then by construction of the tax rate (17) that combining (17) with (22) yields an equations identical to (23) 


\section{Appendix B - Numerical Solution Method}

The algorithm employed to solve for the recursive competitive decentralized equilibrium is the following:

1. Start with an initial set of parameters $\{\beta, \omega, \kappa\}$

2. Generate a discrete grid for the economy's asset of size $N B$ and the shock state space $N S$.

3. Conjecture a law of motion for aggregate net foreign assets $B^{\prime}=\Gamma\left(B, y^{T}\right)$ at each point of the state space, which implies a price given by (10).

4. Solve for the policy functions $\left\{\hat{b}\left(b, B, y^{T}\right), \hat{c}^{T}\left(b, B, y^{T}\right), \hat{c}^{N}\left(b, B, y^{T}\right)\right\}$ via value function iteration in the Bellman equation (11).

5. Using the decision rules in the previous step, calculate the effective law of motion of aggregate bonds $\hat{b}\left(B, B, y^{T}\right)$ and evaluate the previous conjecture. If $\sup _{B, y^{T}} \| \hat{b}\left(B, B, y^{T}\right)-$ $\Gamma\left(B, y^{T}\right) \|<\epsilon$, the recursive competitive equilibrium is found. Otherwise, update $\Gamma\left(B, y^{T}\right)$ with a Gauss-Seidel algorithm and go to step 4.

6. Simulate the model. If the defined model's moments match the data, we stop. Otherwise, adjust parameters and grid and go to step 3.

We use 80 points in the grid for individual and aggregate bonds with relatively more points located at the beginning of the grid where the value function displays more curvature. ${ }^{36} \mathrm{We}$ choose the first and the last point in the grid so that they are not binding in the ergodic distribution. To solve for the optimization problem in step 4, we do not restrict the choice of assets to lie in the grid. We use various interpolation schemes to compute the value function at points not on the grid. Linear interpolation and Schumaker spline preserving shape do not deliver noticeable differences. In order to solve the constrained optimization problem, we first assume that the credit constraint is binding and calculate the marginal utility of relaxing the constraint. If the marginal utility is positive, the solution is at the boundary. Otherwise, we solve for the optimization solution when the credit constraint does not bind, using a bisection procedure. Because it is a strictly concave optimization problem with a convex constraint set, the method guarantees that the global maximum is achieved. To accelerate the algorithm, we use Howard improvement steps and the grid refinement proposed by Chow

\footnotetext{
${ }^{36}$ Increasing the grid to 160 points does not produce noticeable differences in the results.
} 
and Tsitsiklis (1991). We start with a coarse grid that we extend to a finer grid (with linear interpolation to fill the unknown values) and recompute the value function. 


\section{Appendix C - Sensitivity Analysis Ctd}

We continue here the sensitivity analysis presented in the body of the paper.

\section{Risk Aversion}

An increase in the risk aversion leads both the social planner and decentralized agents to accumulate more precautionary savings and to become less exposed to financial crises. This result is reflected in lower probabilities of financial crisis, as Table 8 shows. When we set the risk aversion parameter equal to 5 , we can see that the distortion created by the externality increases. The reason is that as risk averse increases, the welfare cost of the risk of a drop in consumption during a crisis becomes higher. Therefore, the social planner who internalizes the social cost of these episodes reduces more debt than decentralized agents when risk aversion is high. In this way, the largest drop in consumption is 20 percent in the decentralized equilibrium and only 7 percent in the social planner's solution.

\section{Credit Coefficient}

A higher $\kappa$ tends to increase the externality term, since when the constraint binds, the social planner internalizes that an increase in wealth would appreciate the real exchange rate and relax the credit constraint proportionally to $\kappa$. On the other hand, if $\kappa$ increases up to a point that the credit constraint never binds in the two environments, there is no debt-deflation effect in equilibrium; therefore, the externality would trivially disappear. When $\kappa$ increases by 4 percentage points, the social planner does not experience a financial crisis in the long run while the decentralized agents still experience a crisis with a 2.3 percent probability in the long run. In a similar way, if $\kappa$ is reduced to zero, there is no debt-deflation effect, and the externality disappears. Reducing $\kappa$ also by 4 percentage points reduces the distortions measured by the differences in the incidence and the severity of financial crises.

\section{Share of tradables}

As the preference for tradable consumption $\omega$ increases, for a given reduction of tradable consumption, the magnitude of the adjustment in the price of non-tradables is lower, but not in percentage, which is only determined by $\mu$. An increase in $\omega$, however, implies a higher preference for tradable consumption and a higher disutility from becoming credit constrained. 
The effect of a change in $\omega$ over the credit externality is therefore qualitatively ambiguous. Quantitatively, an increase in $\omega$ of 0.04 , which makes the share of tradable output equal to 0.36 (versus 0.32 in the baseline), tends to reduce the effects of the externality. A decrease in $\omega$ of 0.04 which makes the share of tradable output equal to 0.30 produces more differences in the severity of a financial crisis measured by the largest drops in consumption.

\section{Standard Deviation}

Finally, changes in the standard deviation of tradable output of around 1 percent do not produce significant changes in the distortions introduced by the credit externality. 